\title{
ŚWIĘTE DZIEWICTWO, KRÓLOWA DZIEWIC I WŁADZA W OTTOŃSKIEJ RZESZY
}

\begin{abstract}
Abstrakt: Artykuł dotyczy znaczenia, jakie w religijności i ideologii władzy w ottońskiej Rzeszy miało święte dziewictwo. Zwraca uwagę na jego szczególną rolę w budowaniu autorytetu ludzi Kościoła obojga płci, a także pozycji władczyni. Pokazuje, że właśnie w kontekście dziewictwa należy rozumieć szczególne związki łączące ich z Marią Panną, traktowaną jako pierwsza ze świętych dziewic i ich królowa. Towarzyszy temu pytanie o związek dziewictwa z płcią, a więc o jego znaczenie tak $\mathrm{w}$ duchowości mężczyzn i kobiet, jak i w proponowanych im wzorach świętości.
\end{abstract}

Słowa kluczowe: dziewictwo, Maria Panna, władza, koronacja, władczyni, dynastia ottońska.
Abstract: The article focuses on the importance of holy virginity for the devotion and ideology of power in the Ottonian Reich. The author pays attention to its special role in establishing the authority of people of the Church, of both genders, and the position of the queen. He demonstrates that it is in the very context of the virginity that their special relationship with the Virgin Mary should be understood, for she was regarded as the first of the holy virgins and their queen. This is accompanied by the question about the relation between virginity and gender, and thus about its significance for the spirituality of men and women as well as models of sanctity offered to them.

Keywords: virginity, Virgin Mary, power, coronation, queen, Ottonian Dynasty.

Primordia coenobii Gandeshamensis, utwór pióra Hrotswity z Gandersheim, w sposób wyjątkowo dobitny pokazuje znaczenie, jakie w myśleniu kręgów ottońskich miało dziewictwo ${ }^{1}$. Z tekstu dowiadujemy się,

${ }^{1}$ O roli dziewictwa i czystości w utworach Hrotswity por. w tomie A Companion to Hrotsvit of Gandersheim (fl. 960). Contextual and Interpretive Approaches, red. P.R. Brown, S.L. Wailes, Leiden-Boston 2013: G. Macy, Hrotsvit's Theology of Virginitity and Continence, 
że Liudolfingowie otrzymali kiedyś od Boga dwie obietnice: że założą wspaniały klasztor dziewic oraz że otrzymają władzę cesarską. To ostatnie zależało jednak właśnie od wypełnienia pierwszego zadania, a więc nie tylko fundacji klasztoru, ale też zatroszczenia się, aby żyjąca w nim wspólnota odznaczała się wyjątkową pobożnością. I rzeczywiście: powstaje klasztor kanoniczek w Gandersheim, o dyscyplinę w nim troszczą się kolejne opatki pochodzące z rodu Liudolfingów, a w efekcie nieustannej czci, jaką dziewice otaczają swego boskiego Oblubieńca, na ród spływa obfitość wszelkich łask, w tym i ta, że potomek założycieli opactwa zostaje cesarzem² ${ }^{2}$. Hrotswita mówi więc ni mniej, ni więcej, tylko że to od dziewictwa zależy władza Ottonów.

To zaskakujące z naszej perspektywy powiązanie władzy i dziewictwa wydaje się, jak postaram się pokazać, czymś charakterystycznym dla postrzegania tego ostatniego w ottońskiej Rzeszy. Dziewictwo stanowiło bowiem źródło autorytetu i ważny element legitymizacji władzy dla praktykujących je ludzi Kościoła, ale też - jak zobaczymy - w pewnym sensie dla władczyni. Przede wszystkim jednak widziano w nim drogę do świętości, a więc do udziału we władzy najwyższej, to jest współrządów niebiańskich z Oblubieńcem-Chrystusem. Wzorem stała się tu koronowana w niebie właśnie w nagrodę za swe dziewictwo Maria Panna, która zarazem prezentowana jest jako ta, za pośrednictwem której dziewice dostępują największego wywyższenia, otrzymując koronę życia wiecznego. Dziewictwo, źródło władzy Bogarodzicy, staje się więc szczególnie ważnym jej przymiotem dla tych wszystkich, którzy wiązali z nim nadzieje na swoje zbawienie, ale i widzieli w nim źródło swego ziemskiego autorytetu.

Dewocja maryjna osób duchownych

Temat powiązań między władzą a Marią Panną w liudolfińskiej Rzeszy był już w badaniach podejmowany. Historycy tacy jak Ernst-Dieter

s. 63-82 (passim) oraz L.M.C. Weston, Virginity and Other Sexualities, s. 267-285 (passim); S.L. Wailes, Beyond Virginity. Flesh and Spirit in the Plays of Hrotsvit of Gandersheim, „Speculum" 76, 2001, 1, s. 1-27 (passim).

${ }^{2}$ Hrotsvit, Primordia coenobii Gandeshamensis, w: Hrotsvit, Opera Omnia, wyd. W. Berschin, Monachii et Lipsiae 2001, s. 306-329. Por. M.T. Szczepański, Proroctwo i obietnica. Nadprzyrodzone przesłanki władzy Ottonów w ujęciu Hrotsvit z Gandersheim, w: Christianitas Romana. Studia ofiarowane Romanowi Michałowskiemu, red. K. Skwierczyński, Warszawa 2009, s. 104-119 (passim); R. Michałowski, Princeps fundator. Studium z dziejów kultury politycznej w Polsce X-XIII wieku, Warszawa 1993, s. 13-18. 
Hehl, Henry Mayr-Harting czy Patrick Corbet ${ }^{3}$ pokazywali więc, że Maria Panna była postacią ważną w dewocji i legitymizacji władzy tak ottońskich królów, jak i królowych.

Aby jednak zobaczyć szerszy kontekst dewocji maryjnej tego okresu, zwłaszcza w interesującym nas aspekcie, przyjrzyjmy się zjawisku, któremu poświęcono mniej uwagi, a mianowicie czci, jaką otaczały Marię Pannę osoby duchowne ${ }^{4}$ i wspólnoty klasztorne. Warto zresztą podkreślić tu i rozpocząć od przykładów przedstawień wiążących ją ze wspólnotami mnichów czy duchownymi mężczyznami, idąc za spostrzeżeniami Kristen M. Collins, która w oparciu o materiał ikonograficzny podkreśla, że „Maria Panna na majestacie była pojemnym wyobrażeniem, mogącym być wyrazem władzy różnorodnych typów patronów - tak patronów cesarskich, jak i monastycznych, tak męskich, jak i żeńskich"5.

Przywołajmy choćby scenę dedykacyjną z pochodzącego z ok. 994 r. kodeksu z Reichenau, na którym obok tronującej Marii Panny zobaczyć możemy rządzącego wówczas opactwem Witigowa, a także świętego opata, założyciela Reichenau Pirmina i towarzyszącą mu grupą mnichów6. Więź łączy więc Bogarodzicę, patronkę najstarszego kościoła klasztornego, tak ze sprawującym rządy opatem, jak i z całą mniszą wspólnotą, co podkreśla także przedstawienie Augii, symbolicznej personifikacji Reichenau? ${ }^{7}$ Jeśli chodzi o biskupów, to w tym kontekście warto przywołać postać Warmunda, biskupa noszącej wezwanie Marii Panny diecezji w Ivrei, który umieszczał maryjne dedykacje czy ilustracje

${ }^{3}$ E.-D. Hehl, Maria und das ottonisch-salische Königtum. Urkunden, Liturgie, Bilder, „Historisches Jahrbuch” 117, 1997, s. 271-310 (passim); H. Mayr-Harting, The Idea of the Assumption of Mary in the West, 800-1200, w: The Church and Mary, red. R.N. Swanson, Woodbridge 2004, s. 91-99; P. Corbet, Les impératrices ottoniennes et le modèle marial. Autour de l'ivoire du château Sforza de Milan, w: Marie. Le culte de la Vierge dans la société médiévale, red. D. Iogna-Prat, É. Palazzo, D. Russo, Paris 1996, s. 109-135 (passim).

${ }^{4}$ Pojęcia tego używam - ze względów praktycznych - w sensie szerszym niż w definicji słownikowej, a mianowicie nie tylko w odniesieniu do osób posiadających święcenia kapłańskie, ale także osób konsekrowanych obojga płci.

5 „The Virgin Majesty was a flexible image capable of expressing the authority of varied patron groups - imperial and monastic, male and female”, K.M. Collins, „Visualizing Mary. Innovation and Exegesis in Ottonian Manuscript Illumination", University of Texas at Austin (rozprawa doktorska, mps), 2007, s. 73.

${ }^{6}$ Karlsruhe, Badische Landesbibliothek, Cod. Aug. perg. 205, fol. 72r. Por. A. Holder, Die Reichenauer Handschriften, t. 1: Die Pergamenthandschriften, Leipzig 1906 (reprint Wiesbaden 1970), nr 205, s. 466-469; J. Prochno, Schreiber- und Dedikationsbild in der deutschen Buchmalerei, t. 1: Bis zum Ende des 11. Jahrhunderts (800-1100), Leipzig-Berlin 1929, nr 27; C.R. Dodwell, D.H. Turner, Reichenau Reconsidered. A Re-assessment of the Place of Reichanau in Ottonian Art, London 1965, s. 1-5, 85-86.

${ }^{7}$ K.M. Collins, op. cit., s. 74-77; C.R. Dodwell, D.H. Turner, op. cit., s. 1-5. 
przedstawiające sceny z życia swej patronki w kolejnych fundowanych przez siebie kodeksach ${ }^{8}$ i sam blisko wiązał się z tą postacią ${ }^{9}$.

Innym przykładem z terenu cesarstwa jest Bernward z Hildesheim, dla którego Maria Panna, patronka jego biskupstwa i katedry ${ }^{10}$, stanowiła niewątpliwie postać w sensie duchowym ogromnie ważnąar. Wśród licznych przejawów jego maryjnej dewocji szczególnie godna uwagi jest dedykacja ołtarza pod wezwaniem Bogarodzicy i innych świętych w krypcie kościoła klasztoru św. Michała w Hildesheim ${ }^{12}$ i powiązane z tym wydarzeniem ofiarowanie ewangeliarza, znanego jako Kosztowny Ewangeliarz (niem. Kostbares Evangeliar) ${ }^{13}$. Uwagę zwraca zwłaszcza umieszczona w nim scena dedykacyjna, wyobrażająca na lewej stronie biskupa Hildesheim, Bernwarda w stroju liturgicznym, przed ołtarzem, prezentującego kodeks, z prawej zaś strony tronującą Marię Pannę z Dzieciątkiem, koronowaną przez dwa anioły ${ }^{14}$ (il. 1). Dwie kwestie wymagają tu podkreślenia. Po pierwsze, mamy tu do czynienia z jednym z pierwszych w sztuce zachodniej przedstawień jej koronacji ${ }^{15}$, po drugie

${ }^{8}$ P.A. Mariaux, Warmond d'Ivrée et ses images. Politique et création iconographique autour de l'an mil, Bern-Berlin-Bruxelles 1997, s. 207-218.

9 Ibidem, zwł. s. 225-236, a ostatnio P. Figurski, Das sakramentale Herrscherbild in der politischen Kultur des Frühmittelalters, „Frühmittelalterliche Studien” 50, 2016, zwł. s. 156.

10 Por. np. H. Goetting, Das Bistum Hildesheim, t. 3: Die Hildesheimer Bischöfe von 815 bis 1221 (1227), Berlin-New York 1984, s. 37, 39.

11 P. Figurski, Duchowość maryjna biskupa Bernwarda z Hildesheim, „Salvatoris Mater” 13, 2011, 1-2, s. 1-49 (passim).

12 O wezwaniu kościoła i ołtarza informują nas: rekonstruowana inskrypcja (Die älteren Hildesheimer Inschriften bis zum Tod Bischofs Hezilos (†1079), wyd. W. Berges, H-J. Riekkenberg, Göttingen 1983, nr 6, s. 54-62; s. 172; por. Die Inschriften der Stadt Hildesheim, t. 2, wyd. Ch. Wulf, H.-J. Rieckenberg, Wiesbaden 2003, nr 10, s. 192-195, gdzie również o problemach $\mathrm{z}$ datacją), dokumenty (Urkundenbuch des Hochstifts Hildesheim und seiner Bischöfe, t. 1, wyd. K. Janicke, Leipzig 1896, nr 38, s. 27; nr 62, s. 57); oraz żywot Bernwarda (Vita Bernwardi episcopi Hildesheimensis auctore Thangmaro, wyd. G.H. Pertz, MGH SS 4, Hannoverae 1841, cap. 47, s. 778, cap. 49, s. 779, cap. 51, s. 780). Por. np. R. Kahsnitz, Inhalt und Aufbau der Handschrift, w: Das Kostbare Evangeliar des Heiligen Bernward, red. M. Brandt, München 1993, s. 27; J.P. Kingsley, The Bernward Gospel. Art, Memory, and the Episcopate in Medieval Germany, University Park 2014, s. 24 oraz s. 124, przyp. 37; K. Algermissen, Persönlichkeit, Leben und Wirken Bernwards, w: Bernward und Godehard von Hildesheim. Ihr Leben und Wirken, red. idem, Hildesheim 1960, s. 71.

13 Por. P. Figurski, Duchowość maryjna, zwł. s. 34, przyp. 133.

${ }^{14}$ Hildesheim, Domschatz und Dom-Museum, Ms. 18, fol. 16v-17r.

15 Por. R. Kahsnitz, Inhalt und Aufbau, s. 28; M. Hageman, Between the Imperial and the Sacred. The Gesture of Coronation in Carolingian and Ottonian Images, w: New Approaches to Medieval Communication, red. M. Mostert, Turnhout 1999, s. 129-130. Wskazać możemy jedynie nieliczne przedstawienia wcześniejsze. Pierwszeństwo należy się dwóm powiązanym ze sobą ściśle w sensie ikonograficznym przedstawieniom anglosaskim, 
zaś trudno nie dostrzec podobieństwa między tym przedstawieniem Bogarodzicy a mało jeszcze rozpowszechnionymi na północ od Alp, za to znanymi z Rzymu przedstawieniami typu Maria Regina ${ }^{16}$. Nie bez racji badacze wskazywali zresztą na italskie podróże biskupa, które zaważyć mogły na sposobie, w jaki przedstawiona została jego patronka ${ }^{17}$.

Wydaje się jednak, że owa inspiracja mogła mieć nie tylko artystyczne, ale i ideologiczne podstawy. W tym miejscu trzeba bowiem zauważyć, że biskup Bernward, podobnie jak i inni duchowni, odwołując się do szczególnej protekcji Marii Panny, postępował podobnie, jak nie kto inny, a sam biskup Rzymu. Właśnie bowiem w ideologii papieskiej już od VIII w. postać Bogarodzicy, a zwłaszcza przedstawienie typu Maria

w Benedykcjonale Etelwolda (Londyn, British Library, Add. 49598, fol. 102 v; datacja: 971-984) i w tzw. Benedykcjonale Roberta z Jumièges (Rouen, Bibliotèque municipale, 369 [Y.7], fol. 54v, datacja ok. 980), gdzie przedstawienie Zaśnięcia Marii wraz z wychylającą się z nieba manus Dei z koroną (w Benedykcjonale Etelwolda otoczoną przez cztery anioły, z których jeden dzierży berło). Por. M. Clayton, The Cult of the Virgin Mary in the Anglo-Saxon England, Cambridge 1990, s. 159-165; M.-L. Thérel, A l'origine du décor du portail occidental de Notre-Dame de Senlis. Le triomphe de la Vierge-Église. Sources historiques, littéraires et iconographiques, Paris 1984, s. 237; R. Deshman, The Benedictional of Æthelwold, Princeton 1995, s. 124-138; Ph. Verdier, Le couronnement de la Vierge. Les origines et les premiers développements d'un thème iconographique, Montréal-Paris 1980, s. 19. Nadto wspomnieć trzeba scenę Zaśnięcia z Antyfonarza z Prüm, gdzie dusza Bogarodzicy, unoszona przez anioła, zostaje przyozdobiona koroną przez manus Dei, Paryż, Bibliothèque nationale de France, Ms lat. 9448, fol. 60v. Datacja patrz: S. Beissel, Miniaturen aus Prüm, „Zeitschrift für christliche Kunst” 19, 1906, 1, kol.11-22, a także Ph. Lauer, Les enluminures romanes des manuscrits de la Bibliothèque nationale, Paris 1927, s. 116-121 (gdzie ogólnie: wiek X). Omawiana scena por. M.-L. Thérel, op. cit., s. 54; Ph. Verdier, op. cit., s. 63, 73; H. Mayr-Harting, The Idea of the Assumption of Mary, s. 95; idem, Ottonian Book Illumination, t. 1, London 1991, s. 145-146. O innych scenach koronacji Marii Panny z tego okresu patrz niżej, s. 830-831 z przyp. 73.

${ }^{16}$ R. Kahsnitz, Inhalt und Aufbau, s. 28-29; E. Guldan, Eva und Maria. Eine Antithese als Bildmotiv, Graz-Köln 1966, zwł. s. 14-18; M. Hageman, op. cit., s. 127-163 (passim). O typie Maria Regina patrz: M. Lawrence, Maria Regina, „The Art Bulletin” 7, 1925, 4, s. 150-161 (passim); D. Russo, Les représentations mariales dans l'art d'Occident. Essai sur la formation d'une tradition iconographique, w: Marie. Le culte de la Vierge, s. 194-209; M.-L. Thérel, op. cit., zwł. s. 231-236; F. Rademacher, Die Regina angelorum in der Kunst des frühen Mittelalters, Düsseldorf 1972, zwł. s. 20-69; a ostatnio M. Lidova, The Earliest Images of Maria Regina in Rome and the Byzantine Imperial Iconography, „Niš \& Byzantium" 8, 2010, red. M. Rakocija, s. 231-243 (passim) oraz literatura wskazana niżej, przyp. 18.

17 R. Kahsnitz, Inhalt und Aufbau, s. 29; M. Hageman, op. cit., s. 131-135. Por. też A.S. Cohen, The Uta Codex. Art, Philosophy, and Reform in Eleventh-Century Germany, University Park 2000, s. 211, przyp. 19. Na temat owych podróży por. W. Goez, Italien zur Zeit Bernwards, w: Bernward von Hildesheim und das Zeitalter der Ottonen, red. M. Brandt, A. Eggebrechtt, t. 1, Hildesheim-Mainz am Rhein 1993, s. 123-132. 
Regina, odgrywało szczególną rolę ${ }^{18}$. Wydaje się, że tak jak w osobie Marii legitymizacji swej władzy szukali papieże, tak też stanowiła ona podobny punkt odniesienia i dla innych duchownych mężczyzn.

Przykład papieski najdobitniej pokazuje też, że wiązanie maryjnego patronatu jedynie czy głównie z postaciami kobiecymi jest więcej niż wątpliwe. Oczywiście nie znaczy to, że Maria Panna nie odgrywała istotnej roli także wśród mniszek czy kanoniczek. Dowodzą tego niektóre dzieła sztuki ottońskiej, które wiązać można ze wspólnotami żeńskimi, w tym z majętnym opactwem w Essen, którego patronką była, obok męczenników Kosmy i Damiana, właśnie Bogarodzica ${ }^{19}$. Najbardziej znanym przykładem jest tu niewątpliwie figura tronującej Złotej Madonny z ostatniej ćwierci X w., pierwotnie wyposażona w królewskie jabłko, a w pewnym, trudnym do określenia momencie - także w nakładaną na jej głowę koronę ${ }^{20}$. Także więc i w tym przypadku punktem odniesienia jest Maria Panna wyobrażona jako władczyni.

18 Por. U. Nilgen, Maria Regina - ein politischer Kultbildtypus, „Römisches Jahrbuch für Kunstgeschichte” 19, 1981, s. 3-33 (passim); T.F.X. Noble, Topography, Celebration, and Power. The Making of Papal Rome in the Eighth and Ninth Centuries, w: Topographies of Power in the Early Middle Ages, red. F. Theuws, M. de Jong, Leiden 2001, s. 45-91, zwł. s. 56-72; idem, Images, Iconoclasm and the Carolingians, Philadelphia 2009, s. 129-134; J. Osborne, The Cult of Maria Regina in Early Medieval Rome, „Acta ad archaeologiam et atrium historiam pertinentia" 21, 2008, s. 95-106 (passim) oraz M. Stroll, Maria Regina. Papal Symbol, w: Queens and Queenship in Medieval Europe, red. A.J. Duggan, Woodbridge 1997, s. 173-203 (passim), gdzie omówiony także okres późniejszy, aż do wieku XIII, a także literatura wskazana wyżej, przyp. 16.

19 Jako taka pojawia się ona, choć nie zawsze, obok Kosmy i Damiana (wśród patronów wymienia się też niekiedy św. Trójcę czy Zbawiciela) w dokumentach, patrz Rheinisches Urkundenbuch. Ältere Urkunden bis 1000, t. 2, wyd. E. Wisplinghoff, red. W.-R. Schleidgen i in., Düsseldorf 1994, nr 159, s. 31; nr 162, s. 36-37; nr 164, s. 40; nr 177, s. 67. Por. np. H. Schoppmeyer, Essen, w: Lexikon des Mittelalters, t. 4, München-Zürich 1989, kol. 22-23; W. Zimmermann, Das Münster zu Essen, Essen 1956, s. 35; R. Kahsnitz, The Gospel Book of Abbess Svanhild of Essen in the John Rylands Library, cz. 1, „Bulletin of the John Rylands Library" 53, 1970-1971, 1, s. 123.

${ }^{20}$ Por. F. Fehrenbach, Die Goldene Madonna im Essener Münster. Der Körper der Königin, Essen 1996; L. Küppers, Die Goldene Madonna in Essen, w: Die Gottesmutter. Marienbild in Rheinland und in Westfalen, red. idem, Recklinghausen 1974, s. 43-50 (passim); L. Küppers, P. Mikat, Der Essener Münsterschatz, Essen 1966, s. 34-39. Datacja korony jest przedmiotem debaty. Większość badaczy idzie tu za niemającą wszelako mocniejszych podstaw propozycją Hermanna Schnitzlera (Rheinische Schatzkammer. Tafelband, Düsseldorf 1957, nr 40, s. 31-32), że jest to korona trzyletniego Ottona III, która już w jego czasach znalazła się w opactwie. Inaczej znawczyni insygniów i biżuterii X i XI w., Mechthild Schulze-Dörrlamm, która odrzuca nie tylko związek z Ottonem, ale i proponuje datację korony na połowę wieku XI, M. Schulze-Dörrlamm, Die Kaiserkrone Konrads II. (1024-1039). Eine archäologische Untersuchung zu Alter und Herkunft der Reichskrone, Sigmaringen 1991, 
Jeśli jednak szukać analogii do sceny dedykacyjnej z Ewangeliarza Bernwarda, to najbardziej adekwatna będzie scena dedykacyjna z Ewangelistarza Uty ${ }^{21}$ (il. 2), opatki ratyzbońskiego Niedermünster w pierwszej ćwierci XI w., a być może także w końcu $\mathrm{X}^{22}$. Na wspólne cechy tych kodeksów, podobnie jak w ogóle na związki między rękopisami hildesheimskiej i ratyzbońskiej proweniencji zwracano już uwagę ${ }^{23}$, choć - co trzeba wyjaśnić - samo podobieństwo interesujących nas tu scen dedykacyjnych jest w sensie formalnym ograniczone ${ }^{24}$. Różni je i sposób ukazania donatora/donatorki, i fakt, że w ratyzbońskim kodeksie przedstawienie zamyka się na jednej stronie. Tym natomiast, co oba przedstawienia łączy, jest po pierwsze temat - także Uta ofiarowuje księgę Marii Pannie, patronce niedawno przebudowanego kościoła w Niedermünster ${ }^{25}$, po drugie zaś sposób przedstawienia Matki Bożej - zasiada ona, ukoronowana, na tronie, trzymając na podołku Dzieciątko. Mamy więc, podobnie jak w przypadku sceny dedykacyjnej z Ewangeliarza Bernwarda, do czynienia z przedstawieniem osoby duchownej szukającej patronatu Marii Panny, a zarazem z kolejnym przedstawieniem należącym do najstarszych wyobrażeń tej ostatniej jako królowej w sztuce na północ od Alp ${ }^{26}$. Jak więc widać, duchowni z czasów rządów Liudolfingów, niezależnie od swej płci, chętnie odwoływali się do protekcji Matki Bożej, a przedstawiając ją - sięgali po jej wyobrażenie na majestacie, jako królowej, podobnie jak czynili to wówczas (i wcześniej) papieże. Same przedstawienia biskupów, opatów czy opatek z Marią Panną widzieć można jako świadectwo ich pobożności, a zarazem próbę powiązania swej własnej władzy i autorytetu z osobą Królowej Nieba.

s. 40, 70-71. Por. P.E. Schramm, Herrschaftszeichen und Staatssymbolik. Beiträge zu ihrer Geschichte vom dritten bis zum sechzehnten Jahrhundert, t. 2, Stuttgart 1955, s. 415; idem, F. Mütherich, Denkmale der deutschen Könige und Kaiser. Ein Beitrag zur Herrschergeschichte von Karl dem Großen bis Friedrich II. 768-1250, München 1962, nr 81, s. 147; H. F[illitz], Krone, w: Bernward von Hildesheim und das Zeitalter der Ottonen, t. 2, nr II-32, s. 79-81; L. Küppers, P. Mikat, op. cit., s. 39-41.

${ }^{21}$ Monachium, Bayerische Staatsbibliothek, Clm 13601, fol. 2r.

22 A. Cohen, The Uta Codex, s. 9-23, gdzie dalsza literatura i streszczenie wcześniejszej dyskusji. O kodeksie por. też idem, The Art of Reform in a Bavarian Nunnery Around 1000, „Speculum” 74, 1999, 4, s. 992-1020.

${ }^{23}$ A. Cohen, The Uta Codex, s. 145; G. Bauer, „Neue” Bernward-Handschriften, w: Bernwardinische Kunst. Bericht über ein wissenschaftliches Symposium in Hildesheim vom 10.10. bis 13.10.1984, red. M. Gosebruch, F.N. Steigerwald, Göttingen 1988, s. 214-216.

${ }^{24}$ Por. R. Kahsnitz, Inhalt und Aufbau der Handschrift, s. 28.

25 A.S. Cohen, The Uta Codex, s. 41.

${ }^{26}$ Por. ibidem, s. 145. 


\section{Maria Panna i święte dziewictwo}

Zastanawiając się nad tą popularnością Marii Panny wśród duchownych, uwzględnić trzeba z pewnością wiele przyczyn, w tym niezależny często od nich maryjny patronat instytucji, na czele których stali, a także prosty fakt, że mamy do czynienia z ważną i potężną świętą. Rację może mieć jednak także Collins, która sugeruje, że istotną rolę mogło tu odgrywać dziewictwo Matki Bożej, czyniące ją idealnym wzorem dla mnichów czy mniszek, ale też dla żyjących w celibacie biskupów ${ }^{27}$.

Znaczenie tej właśnie kwestii zdają się potwierdzać przedstawienia Bogarodzicy w kodeksach ufundowanych przez Bernwarda i Utę, a ściśle - teksty towarzyszące obu omawianym wyżej scenom, z pewnością godne uwagi. W Kosztownym Ewangeliarzu, na bordiurze lewej strony, przedstawiającej Bernwarda przy ołtarzu ofiarującego księgę, czytamy więc: „Tę książeczkę Ewangelii w gorliwości ducha wręcza Ci, święta Mario, miłośnik dziewictwa, biskup Bernward”28. Określenie „miłośnik dziewictwa", jak słusznie zauważa Paweł Figurski, może mieć tu dwa aspekty - odnosić się do dziewictwa samej Marii Panny, którą to cechę szczególnie upodobał sobie u niej jej czciciel, jak i do dziewictwa jako takiego, w którym sam biskup - jak tu podkreśla - partycypuje ${ }^{29}$. Oba aspekty można połączyć, dostrzegając, że właśnie dziewictwo jest tym, co w sposób szczególny wiąże Bernwarda z osobą Panny Marii.

Dla biskupa ma ono zresztą szczególne znaczenie nie tylko w wymiarze stricte religijnym, ale także w kontekście władzy i autorytetu. Warto pamiętać, że choć w interesującym nas okresie przestrzeganie celibatu wśród kleru nie było jeszcze bynajmniej normą ${ }^{30}$, to wśród biskupów Rzeszy trudno znaleźć żonatych. Do Kościoła ottońskiego można więc odnieść myśl, jaką wyrażono na temat współczesnego mu Kościoła w Anglii: choć ciągle nie brakowało w nim żonatych księży, do władzy dochodzili tylko ci oddani dziewictwu ${ }^{31}$. Podkreślając więc swe przywiązanie do dziewictwa i związek z uosabiającą poniekąd ideę świętego

${ }^{27}$ K.M. Collins, op. cit., s. 79; P. Figurski, Duchowość maryjna, s. 26.

28 „Hoc evangelicu(m) devota m(en)te libellum / Virginitatis amor pr(ae)stat tibi $\mathrm{s}(\mathrm{an}) \mathrm{c}(\mathrm{t}) \mathrm{a}$ Maria / praesul Bernward(us)".

29 Por. P. Figurski, Duchowość maryjna, s. 26.

30 Por. np. R. Michałowski, Święty Wojciech - biskup reformator w Europie X wieku, w: Granica wschodnia cywilizacji zachodniej w średniowieczu, red. Z. Dalewski, Warszawa 2014, s. 186-198, gdzie dalsza literatura.

${ }^{31}$ F. Lifshitz, Priestly Women, Virginal Men. Litanies and Their Discontents, w: Gender and Christianity in Medieval Europe. New Perspectives, red. L.M. Bittel, F. Lifshnitz, Philadelphia 2008, s. 101-102. 
dziewictwa Marią, Bernward odnosi się także do kwestii legitymizujących jego pozycję jako biskupa.

Nie inaczej jest, rzecz jasna, w wypadku rządzącej wspólnotą dziewic Utą, której władza wobec mniszek i autorytet na zewnątrz klasztornych murów w sposób oczywisty związane są z jej dziewictwem. Także więc i w kodeksie Uty fundatorka, wiążąc się z Marią Panną, w sposób szczególny podkreśla ten właśnie aspekt. Obok tytułu Theotokos oraz stella maris („Gwiazda morza”), Maria jest tu więc nazwana także virgo virginum („Dziewica dziewic” czy „Dziewica ponad dziewicami”). Ten ostatni tytuł, choć spotykany, nie należał - wbrew pozorom - w wieku XI do szczególnie częstych; standardowy byłby raczej zwrot semper virgo („Zawsze Dziewica”). Zwracając uwagę na ten fakt, Adam S. Cohen przypuszcza, że określenie to, podobnie zresztą jak także dość nietypowe i pojawiające się na tym przedstawieniu domina mundi („Pani świata”), mogło zostać zapożyczone z antyfony bożonarodzeniowej ${ }^{32}$. Próbując zaś wytłumaczyć jego zastosowanie, stwierdza, że określenie virgo virginum „odnosi dziewictwo Marii Panny [--] do grupy ziemskich dziewic, dla których jest ona wzorem. Termin precyzuje, że Maria jest paradygmatyczną Dziewicą dziewic z Niedermünster, które - podobnie jak Matka Boża - są zaślubione Chytrusowi"33. Stojąca zatem na czele tej wspólnoty Uta odwołuje się wprost do tej, z którą podległe jej mniszki są związane w sposób szczególny.

Koncepcja, aby łączyć ze sobą konsekrowane dziewice i Marię Pannę nie jest, rzecz jasna, nowa, daje się ją zauważyć już w czasach Ojców Kościoła ${ }^{34}$, a w De virginitate Wenancjusza Fortunata czytamy, że to właśnie ona prowadzi „dziewicze owce z orszaku Baranka”35. Z grupą dziewic zestawia też Marię Pannę w swym kazaniu Legimus Helizachar, kanclerz Ludwika Pobożnego, gdy wymienia kolejne kategorie świętych ${ }^{36}$.

32 A.S. Cohen, The Uta Codex, s. 47 wraz z przyp. 33 (s. 213).

33 „Virgo virginum, on the other hand, relates Mary's virginity to [- - ] group of human virgins for whom Mary is the model. The term thus specifies that Mary was the paragmatic Virgin of the virgins of Niedermünster, who, like the Mother of God, were espoused to Christ", ibidem, s. 47-48 (cytat: s. 47)

${ }^{34}$ Por. D. Elliot, The Bride of Christ Goes to Hell. Metaphor and Embodiment in the Lives of Pious Women, 200-1500, Philadelphia 2012, s. 41-42.

35 „Inde dei genetrix pia virgo Maria coruscat, / virgineoque agni de grege ducit oves. / ipsa puellari medio circumdata coetu / luce pudicitiae splendida castra trahit", De virginitate, w: Venanti Honori Clementiani Fortunati presbyteri Italici opera poetica, wyd. F. Leo, MGH Auct. Ant., t. 4, cz. 1, Berolini 1881, ks. 8, pieśń 3, s. 182, w. 25-28. Por. D. Elliot, op. cit., s. 90.

36 „Beata Dei genetrix et semper uirgo Maria [--] presentis solemnitate diei, cum suis uirginibus, expers nullo modo credenda est", Legimus in ecclesiasticis historiis, wyd. 
To właśnie w okresie karolińskim następuje zresztą wyraźne zbliżenie między dziewictwem Marii Panny a konsekrowanym dziewictwem - to pierwsze zostało zaplanowane przez Boga jako wzór, a zarazem uwznioślenie tego drugiego ${ }^{37}$. Paschazjusz Radbertus w Cogitis me mówi więc o Bogarodzicy jako o „przykładzie doskonałości dla dziewic” ${ }^{38}$, w podobnym duchu pisze wcześniej i Paweł Diakon ${ }^{39}$.

Choć trudno zaprzeczyć, że większość autorów, mówiąc o związku Marii Panny z konsekrowanym dziewictwem, łączyło ją w sposób szczególny z mniszkami i kanoniczkami, a nie mnichami, to przecież we wcześniejszym średniowieczu istniała też świadomość, że rzecz niekoniecznie powiązana musi być z płcią. We wspomnianym przed chwilą kazaniu Helizachara Maria Panna przedstawiona jest jako przykład dla tych wszystkich, „obojga płci”, którzy - odrzuciwszy małżeństwo - wybrali „Oblubieńca, który jest w niebie”40. Nieco późniejszy autor, Notker z St. Gallen, zwraca się natomiast do Bogarodzicy w swym hymnie na Wniebowzięcie: „Ciebie naśladuje tłum obojga płci tych, którzy umiłowawszy życie dziewicze, we wstrzemięźliwości naśladują mieszkańców Nieba"41.

J.E. Cross, w: J.E. Cross, „Legimus in ecclesiasticis historiis”. A Sermon for All Saints, and its use in Old English Prose, „Traditio” 33, 1977, s. 117, w. 165-167. Por. D. Iogna-Prat, Le culte de la Vierge sous le règne de Charles le Chauve, „Les Cahiers de Saint-Michel de Cuxa” 23, 1992, s. 101-102, gdzie także o zmianie, jaka zaszła w tekście między wiekiem IX a jednym z manuskryptów z końca wieku XI, gdzie Maria Panna otrzymała nie tylko dodatkowe tytuły (patrz: J.E. Cross, op. cit., Appendix 1, s. 121-122), ale też znalazła się na samym początku listy świętych.

37 Por. L. Scheffczyk, Das Mariengeheimnis in Frömmigkeit und Lehre der Karolingerzeit, Leipzig 1959, zwł. s. 177; J. Bugge, Virginitas. An Essay in the History of a Medieval Idea, The Hague 1975, zwł. s. 148-150; G. Pac, Królowa-Matka czy Królowa-Oblubienica? Przemiany w rozumieniu królewskiego statusu Marii Panny i jej relacji z Chrystusem w teologii karolińskiej, w: Płeć i władza w kontekstach historycznych i współczesnych, red. M.A. Kubiaczyk, F. Kubiaczyk, Gniezno 2014, zwł. s. 123.

38 „Ecce, Iesu ascendente, cum quibus uirgo uacat in schola uirtutum et meditatur in lege mandatorum Dei, ut et ipsa sit forma disciplinae Christi et exemplum perfectionis uirginibus”, Der Pseudo-Hieronymus-Brief IX „Cogitis Me”, Ein erster Marianischer Traktat des Mittelalters von Paschasius Radbert, red. i wstęp A. Ripberger, Freiburg 1962, cap. 20, s. 66, por. też s. 64-65. Por. J. Bugge, op. cit., s. 149-150; L. Scheffczyk, op. cit., zwł. s. 417-420.

39 Paulus Winfridus Diaconus, Homilia II, PL 95, kol. 1573. Por. J. Bugge, op. cit., s. 148.

40 „Ita ut innumerabilis utriusque sexus multitudo eius sequebatur uestigia, ut relictis nuptiarum copulationibus spretoque liberorum propagine, sponso, qui in caelis est, perenni mente, actu, abitu et gestu, adplicare maluerint", Legimus in ecclesiasticis historiis, s. 118, w. 171-174. Por. D. Iogna-Prat, Le culte de la Vierge, s. 101.

41 „Te plebes / sexus sequitur utriusque, / vitam diligens virginalem, / caelicolas / in castimonia aemulans", In Assumptione Sanctae Mariae, wyd. W. von den Steinen, 
W X w. tymczasem - jak pokazał Dominique Iogna-Prat - utożsamienie się z dziewicami stanie się dla mnichów, zwłaszcza z kręgów reformatorskich, podstawowym elementem tożsamości ${ }^{42}$. I tak Abbon z Fleury w Liber Apologeticus, w słynnym ustępie, w którym dzieli ludzi na trzy stany, gdy opisuje ten najlepszy, trzeci, dokonuje utożsamienia: „tertius virginum vel sanctimonialium [--] tertius [est] monachorum"43. Myśl ta stanie się kluczowa dla kluniatów, którzy powiążą to ze szczególnym kultem maryjnym ${ }^{44}$. Odylon, komentując wspominany już tekst pseudo-Hieronima (w istocie autorstwa Paschazjusza Radberta), Cogitis me, stwierdza, że z tego właśnie utworu „dziewice kobiety, lecz nie tylko dziewice kobiety, ale też dziewice mężczyźni mogą nauczyć się, jak powinni dziewiczo i mężnie wojować dla Dziewicy dziewic"45. Jak widzimy, Odylon używa tu tego samego pojęcia, którego Uta użyła na określenie Marii Panny, w kontekście własnej wspólnoty; wydaje się też, że to właśnie dziewictwo było tą cechą Bogarodzicy, która dla Odylona czyniła ją szczególnie użytecznym modelem i wzorem naśladowania dla podległych mu mnichów ${ }^{46}$.

w: Notkeri Liber Ymnorum editio princeps authentica latine et theotisce (= W. von den Steinen, Notker der Dichter und seine geistige Welt, Editionsband), Bern 1948, s. 66. Por. L. Scheffczyk, op. cit., s. 177.

42 D. Iogna-Prat, Entre anges et hommes. Les moines „doctrinaires” de l'an Mil, w: La France de l'an Mil, red. R. Delort, Paris 1990, s. 258-259; Por. S. MacLean, Reform, Queenship and the End of the World in Tenth-Century France. Adso's "Letter on the Origin and Time of the Antichrist” Reconsidered, „Revue belge de philologie et d'histoire” 86, 2008, s. 654-656.

43 Abbo, Liber Apologeticus, PL 139, kol. 463B. Por. D. Iogna-Prat, Entre anges et hommes, loc. cit.; E. Dachowski, Tertius est optimus. Marriage, Continence, and Virginity in the Politics of Late Tenth- and Early Eleventh-Century Francia, w: Medieval Purity and Piety. Essays on Medieval Clerical Celibacy and Religious Reform, red. M. Frassetto, New York-London 1998, s. 117-129 (passim).

${ }_{44}$ Por. D. Iogna-Prat, Entre anges et hommes, s. 256-258.

45 „In eodem vero sermone possunt addiscere virgines feminae, et non solum virgines feminae, sed etiam virgines masculi, quomodo debeant virginum virgini, virginaliter ac viriliter militare", Odilonis Cluniacensis abbatis sermo XII. De assumption Dei genitricis Mariae, PL 142, kol. 1028A.

${ }^{46}$ Por. G.M. Cantarella, Dziewictwo i Cluny, w: idem, Comites aulae coelestis. Studia z historii, kultury i duchowości Cluny w średniowieczu, red. T.M. Gronowski OSB, K. Skwierczyński, Kraków 2009 (oryg. wł. artykułu: 2004), zwł. s. 549-552; D. Iogna-Prat, Continence et virginité dans conception clunisienne de l'ordre du monde autour de l'an mil, „Comptes rendus des séances de l'Académie des Inscriptions et Belles-Lettres” 129, 1985, 1, s. 127-146 (passim); idem, Politische Aspekte der Marienverehrung in Cluny um das Jahr 1000, w: Maria in der Welt. Marienverehrung im Kontext der Sozialgeschichte 10.-18. Jahrhundert, red. C. Opitz, H. Röckelein, G. Signori, G.P. Marchal, Zürich 1993, s. 243-251 (passim); P. Figurski, Duchowość maryjna, s. 27-28. 


\section{Palma virginitatis}

Owo powiązanie Marii Panny i dziewictwa jest też wyraźne w ikonografii i to - ponownie - związanej z Hildesheim i biskupem Bernwardem. Otóż na tylnej oprawie Kosztownego Ewangeliarza (il. 3) widnieje przedstawienie Marii Panny z Chrystusem na ręku, trzymającej także palmową gałązkę. Podobnie palmę dzierży też Bogarodzica przedstawiona w scenie Zwiastowania na pochodzących z czasów Bernwarda drzwiach katedralnych ${ }^{47}$. Warto zauważyć, że palma nie jest wcale wyjątkowym atrybutem Marii Panny ${ }^{48} \mathrm{w}$ tych czasach, ale stanowi oryginalny, nieznany $\mathrm{w}$ kręgu greckim dodatek sztuki zachodniej, przy czym - jak zwracał uwage Robert Deshman - występuje on niemal wyłącznie w sztuce anglosaskiej, stąd takich właśnie, angielskich inspiracji dopatrywał się badacz w przedstawieniu z oprawy Kosztownego Ewangeliarza ${ }^{49}$. I faktycznie wskazać możemy kilka wyspiarskich przedstawień Marii Panny z X i XI w., na których wyobrażona jest ona z palmą lub też - na tablicach kanonów - z palmą lub zieloną, niekiedy kwitnącą różdżką ${ }^{50}$. Innym przykładem jest scena Wniebowzięcia z powstałego około połowy wieku XI Sakramentarza z Mont Saint-Michel, gdzie podtrzymywana przez anioły ukoronowana Maria w prawej ręce dzierży właśnie palmę $e^{51}$.

Interpretacje palmy w ręku Marii Panny bywają różne. Można by w niej mianowicie widzieć symbol męczeństwa, nie kto inny bowiem, a Paschazjusz Radbert dowodził w Cogitis me, że Bogarodzica była i dziewicą, i męczennicą, w istocie przewyższającą pozostałych męczenników, cierpiała bowiem nie fizycznie, ale w głębi swej duszy, widząc ukrzyżowanego Syna ${ }^{52}$. Palma męczeństwa jest symbolem odniesionego przez męczenników zwycięstwa i właśnie jako jego znak interpretuje ten atrybut Bogarodzicy w sztuce anglosaskiej Mary Clayton. Chodzić by tu miało

47 W. Tronzo, The Hildesheim Doors. An Iconographic Source and Its Implications, „Zeitschrift für Kunstgeschichte” 46, 1983, 4, s. 365; R. Ka[hsnitz], Bronzetüren im Dom, w: Bernward von Hildesheim und das Zeitalter der Ottonen, t. 2, nr VII-33, s. 510; M. Brandt, Der Einband, w: Das Kostbare Evangeliar, s. 57.

48 Tak: P. Figurski, Duchowość maryjna, s. 14.

${ }^{49}$ R. Deshman, Christus rex et magi reges. Kingship and Christology in Ottonian and Anglo-Saxon Art, „Frühmittelalterliche Studien” 10, 1976, s. 397. Por. W. Tronzo, loc. cit.; R. Ka[hnitz], Bronzetüren, loc. cit.

${ }^{50}$ R. Deshman, Christus rex et magi reges, loc. cit.; M. Clayton, The Cult of the Virgin Mary, s. 158-159, 167-169, 171-172.

51 Nowy Jork, Pierpont Morgan Library, Ms. 641, fol. 143r. Por. Ph. Verdier, op. cit., s. 68-69, 78 wraz z il. 67.

52 Der Pseudo-Hieronymus-Brief IX „Cogitis Me”, cap. 90, s. 100-101. Por. M. Clayton, The Cult of the Virgin Mary, s. 221; F. Lifshitz, op. cit., s. 91. 
mianowicie o wiktorię odniesioną przez Chrystusa dzięki przyjęciu, za pośrednictwem Matki Bożej, ludzkiej natury ${ }^{53}$. Ze zwycięstwem łączy palmę z przedstawień maryjnych także Deshman i przywołuje apokryficzne przekazy o zapowiedziach śmierci Marii, w których pojawia się anioł, ukazujący ją z triumfalną gałązką palmową ${ }^{54}$. Badacz polemizuje tu z propozycją Rudolpha Wessenberga, który proponował, aby palmę w związanych z Bernwardem przedstawieniach Marii Panny wiązać właśnie z dziewictwem ${ }^{55}$.

Wydaje się jednak, że to tę ostatnią interpretację uznać należy za trafioną. To podkreślenie czystości Bogarodzicy pasuje zresztą do obserwacji Cohena i Anne Derbes ${ }^{56}$, że Ewa, która na drzwiach hildesheimskich postawiona jest w opozycji do Marii Panny ${ }^{57}$, wyobrażona jest tu w sposób szczególnie podkreślający jej kobiecość i seksualność. Na rozumienie palmy z przedstawień związanych z Bernwardem jako symbolu dziewictwa wskazuje jednak przede wszystkim szerszy kontekst. Na przywołanych wyżej, anglosaskich przedstawieniach z tabel kanonów Maria Panna, dzierżąca już to palmę, już to rodzaj berła-różdżki, które może, choć nie musi nawiązywać do palmy, występuje zawsze w otoczeniu innych świętych kobiet, a zwykle - w sensie wizualnym - nieco powyżej nich ${ }^{58}$. Zdaje się to łączyć jej wyobrażenie $z$ tym właśnie atrybutem z dziewicami; jak zauważa Clayton, Maria jest tu ukazana jako virgo virginum ${ }^{59}$.

Mocniejszych dowodów powiązania między palmą a dziewictwem dostarczają jednak współczesne źródła z obszaru Rzeszy, jak scena dedykacyjna Kodeksu Hitdy (il. 4), wyobrażająca tę ostatnią ofiarowującą

53 M. Clayton, The Cult of the Virgin Mary, s. 159, 168.

${ }^{54}$ R. Deshman Christus rex et magi reges, s. 397, przyp. 138. Tak też, jako nawiązanie do zapowiedzi śmieci Bogarodzicy w Transitus Mariae, interpretuje palmę Bernhard Gallistl, Die Tür des Bischofs Bernward und ihr ikonographisches Programm, w: Le porte di bronzo dall'antichità al secolo XIII, t. 1: Testi, red. S. Salomi, Roma 1990, s. 162-163.

${ }^{55}$ R. Wessenberg, Bernwardinische Plastik. Zur ottonischen Kunst unter Bischof Bernward von Hildesheim, Berlin 1955, s. 77 wraz z przyp. 188. Dyskusja ta została poniekąd powtórzona, jako że pogląd Wessenberga przyjął Rainer Kahsnitz (Bronzetüren, loc. cit.), a polemikę z nim - bez znajomości pracy Wessenberga oraz tekstu Deshmana podjęto w pracy: A.S. Cohen, A. Derbes, Bernward and Eve at Hildesheim, „Gesta” 40, 2001, 1, s. 32, gdzie wskazanie na palmę jako symbol zwycięstwa, z nawiązaniem do konfliktu wokół Gandersheim.

56 A.S. Cohen, A. Derbes, op. cit., s. 21-24.

57 Ibidem, s. 19-38 (passim); E. Guldan, op. cit., zwł. 13-26; W. Tronzo, op. cit., s. 366 .

58 M. Clayton, The Cult of the Virgin Mary, s. 171-172.

59 Ibidem, s. 172. 
ewangeliarz św. Walpurgii, która była patronką domu kanoniczek w Meschede, na którego czele stała Hitda ${ }^{60}$. Święta Walpurgia, pochodząca z Anglii opatka, znana była jako misjonarka obszarów niemieckich, inaczej jednak, niż wielu jej kolegów misjonarzy, nie doświadczyła męczeńskiej śmierci, ale zmarła w założonym przez siebie klasztorze. Nie może więc budzić wątpliwości, że palma, z którą jest tu wyobrażona, nawiązuje do jej stanu, a mianowicie konsekrowanego dziewictwa ${ }^{61}$. Wreszcie tego rodzaju połączenie, wyrażone expressis verbis, znajdziemy także w tekstach pisanych, spośród których w tym miejscu przywołajmy jedynie fragment Kroniki Thietmara. Opisując mianowicie śmierć dwóch kanoniczek z Gernrode, biskup merseburski stwierdza, że jedna z nich - ta, która zmarła wcześniej - wyprzedziła drugą „cum palma virginitatis”62.

Powiązanie palmy w rękach Marii Panny w dziełach związanych z Bernwardem potwierdza powyższe uwagi dotyczące szczególnego znaczenia tej właśnie cnoty Bogarodzicy dla biskupa. Tak jak mnichom kluniackim, tak i biskupowi hildesheimskiemu Maria jest szczególnie bliska właśnie jako dziewica, właśnie też jako dziewica jest dla niego, żyjącego w celibacie duchownego, szczególnym źródłem władzy związanej z jego posługą.

\section{Królowa dziewic}

Wracając do kwestii uwypuklających dziewictwo Marii Panny przedstawień ze scen dedykacyjnych ukazujących ją razem z biskupem Bernwardem i opatką Utą, podkreślić trzeba jeszcze jedno. Jak już zauważyliśmy, jest ona tu pokazana - rzecz nadal rzadka na północ od Alp - jako królowa. Wydaje się, że nie jest to przypadek. Owo przedstawienie w sposób szczególny podkreśla, że może być ona źródłem władzy i autorytetu, tak jak to miało miejsce w papieskim Rzymie, gdzie wyobrażenie

${ }^{60}$ Darmstadt, Universitäts- und Landesbibliothek, Cod. 1640, fol. 6r. O kodeksie ostatnio obszernie teksty zawarte w zbiorze: Äbtissin Hitda und der Hitda-Codex (Universitäts- und Landesbibliothek Darmstadt, Hs. 1640). Forschungen zu einem Hauptwerk der ottonischen Kölner Buchmalerei, red. K.G. Beuckers, Darmstadt 2013. Warto zauważyć, że wśród badaczy nie ma zgody co do datacji ewangeliarza, z propozycjami od końca wieku X do połowy XI. Streszczenie dyskusji z przywołaniem obszernej literatury ibidem, zwł. artykuły: K.G. Beuckers, Ch. Winterer, Einleitung, s. 7-32 (passim) oraz D. Riemer, Neue Überlegungen zu Hitda, s. 33-56 (passim).

61 Por. M. Brandt, loc. cit.

${ }^{62}$ Thietmari Merseburgensis episcopi Chronicon, wyd. R. Holtzmann, MGH SrG, Nova series, t. 9, Berolini 1935, VII, 3, s. 402. Por. R. Wessenberg, op. cit., s. 77, przyp. 188; M. Brandt, loc. cit. 
Maria Regina pełniło wyjątkową, polityczną rolę. Jednocześnie zaś istnieje pewien związek między dziewictwem Marii Panny a jej królewskością; także obecność aniołów koronujących Matkę Bożą w scenie dedykacyjnej Kosztownego Ewangeliarza ma - jak zobaczymy później - swoje uzasadnienie.

Ów związek dostrzec można przede wszystkim w wypracowanym jeszcze przez teologię karolińską sposobie rozumienia dnia Wniebowzięcia Bogarodzicy jako jednocześnie momentu jej zaślubin z Niebiańskim Oblubieńcem i jej niebiańskiej koronacji63. Cogitis me, słusznie chyba uchodzące za „podsumowanie ówczesnej myśli na temat Wniebowzięcia” ${ }^{64}$, łączy mianowicie oba wątki. $Z$ jednej więc strony cytuje przeznaczoną na ten dzień antyfonę „Dziewica Maria wyniesiona jest do niebiańskiej komnaty oblubieńczej, gdzie Król królów zasiada na swym gwiaździstym tronie” oraz „Dziś Dziewica Maria została wyniesiona do niebios. Radujcie się, gdyż na wieki króluje z Chrystusem" ${ }^{65}$. Z drugiej tekst stwierdza wprost, że dzień Wniebowzięcia jest dniem, gdy Matka i Dziewica weszła do Nieba i sama zasiadła na królewskim tronie ${ }^{66}$. Maria zostaje więc władczynią właśnie jako dziewica i oblubienica Boskiego Oblubieńca.

Jednoczenie w jednym z najwcześniejszych tekstów, w którym Maria Panna nazwana jest królową, dzieje się to właśnie w związku z jej dziewiczym stanem ${ }^{67}$. Mam tu na myśli powstałą w drugiej połowie VI lub w VII w., opartą zresztą na starszych, greckich wzorach, Ewangelię Pseudo-Mateusza ${ }^{68}$. Jest to tekst o tyle dla nas ważny, że cieszył się on

${ }^{63}$ Por. G. Pac, Królowa-Matka czy Królowa-Oblubienica?, s. 124-126, gdzie dalsze źródła i literatura.

${ }^{64}$ L. Scheffczyk, op. cit., s. 469.

65 Der Pseudo-Hieronymus-Brief IX „Cogitis Me”, cap. 23, s. 67-68. Por. ibidem, Konkordanz, s. 149; L. Scheffczyk, op. cit., s. 469. Teksty antyfon: Corpus Antiphonalium Officii, wyd. R.-J. Hesbert, t. 1: Manuscripti „Cursus Romanus”, Roma 1963, nr 106, s. 286. W manuskrypcie Antyfonarza z Compiègne zachowały się jedynie incypity; tekst w pełnym brzmieniu: „Maria virgo assumpta est ad aetherem thalamum, in quo Rex regum stellato sedet solio [--] Hodie Maria virgo coelos ascendit; gaudete, quia cum Christo regnat in aeternum", patrz: PL 78, kol. 799. Por. E.A. Matter, The Voice of My Beloved. The Song of Songs in Western Medieval Christianity, Philadelphia 1990, s. 153-154; R. Fulton, „Quae est ista quae ascendit sicut aurora consurgens?". The Song of Songs as the Historia for the Office of the Assumption, „Mediaeval Studies” 60, 1998, s. 94-95.

${ }^{66}$ „Haec est, inquam, dies, in qua usque ad throni celsitudinem intemerata mater et uirgo processit atque in regni solio sublimata post Christum gloriosa resedit", Der Pseudo-Hieronymus-Brief IX „Cogitis Me”, s. 74-75. Por. H. Mayr-Harting, The Idea of the Assumption of Mary, zwł. s. 88.

${ }^{67}$ M. Clayton, The Cult of the Virgin Mary, s. 249.

${ }^{68}$ Libri de Nativitate Mariae. Pseudo-Matthaei Evangelium. Textus et commentarius, wyd. J. Gijsel, Corpus Christianorum, Seria Apocryphorum, t. 9, Turnhout 1997, zwł. s. 1-15; 
we wczesnym średniowieczu niezwykłą popularnością: dość powiedzieć, że apokryf ten znany jest nam ze 130 rękopisów ${ }^{69}$, a w Anglii doczekał się też staroangielskiego przekładu, znanego nam z trzech kopii ${ }^{70}$. W Rzeszy o jego znajomości świadczy m.in. fakt powstania jego poetyckiej adaptacji, jaką jest utwór Maria, który Hrotswita z Gandersheim dedykowała opatce swego klasztoru, Gerberdze ${ }^{71}$. Wedle tak apokryfu, jak i jego adaptacji, Maria Panna została jako dziewczyna oddana do świątyni, gdzie służyła razem z innymi dziewicami. Inne panny wyśmiewały ją jednak, żartem nazywając „królową dziewic” (regina virginum) czy też - w wersji Hrotswity - „naszą królową” (regina nostra). Wnet pojawił się jednak anioł, który u Pseudo-Mateusza gani je, a w poemacie Maria pociesza na osobności bohaterkę, wyjaśniając, że określenie jej w ten sposób jest w istocie prorocze; u Hrotswity dodaje, że tylko Maria może stać się „królową na wieki” i „słynną panią gwiaździstego nieba”72.

Scena ta znalazła swoje bezpośrednie niemal przełożenie w ikonografii, w postaci dwóch miniatur z pierwszej połowy XI w., przedstawiających przyjęcie Marii Panny do świątyni, czemu towarzyszy - jak u Pseudo-Mateusza - pojawienie się anioła, który wychyla się z nieba i nakłada na głowę przyszłej Matki Bożej koronę czy też wieniec ${ }^{73}$. Nawiązanie do

J. Gijsel, Die unmittelbare Textüberlieferung des sog. Pseudo-Matthäus, Brussel 1981, zwł. s. 11-15; M. Clayton, The Cult of the Virgin Mary, s. 13; eadem, The Apocryphal Gospels of Mary in Anglo-Saxon England, Cambridge 1998, s. 18; A.S. Cohen, The Uta Codex, s. 214, przyp. 48.

${ }^{69}$ M. Clayton, The Cult of the Virgin Mary, s. 13-14. Pełne zestawienie zachowanych rękopisów podaje Jan Gijsel w: Die unmittelbare Textüberlieferung oraz Libri de Nativitate Mariae. Pseudo-Matthaei Evangelium.

70 M. Clayton, The Cult of the Virgin Mary, s. 248-249; eadem, The Apocryphal Gospels, zwł. s. 136-141; rękopisy: ibidem, s. 117-121; wydanie tekstu z tłumaczeniem angielskim oraz wstęp do wydania: ibidem, s. 153-209.

${ }^{71}$ Hrotsvit, Prologus [I] ad Gerbergam abbatissam, w: Hrotsvit, Opera Omnia, s. 3. Por. M. Goullet, Hrotsvita de Gandersheim, Maria, w: Marie. Le culte de la Vierge, s. 442-443.

72 „Et haec dicentes in fatigationis sermone coeperunt eam reginam uirginum appelare. Cumque haec agerent inter se, apperuit angelus in medio earum et dixit: Non erit iste sermo inemissis, sed in praeuaticinatione uerissima prophetatis", Libri de Nativitate Mariae. Pseudo-Matthaei Evangelium, ks. VIII, 5, s. 374-375 (cytat: s. 375); „Astans sed cicius custos semper sibi fidus / Angelus astrigera dilapsus dixit ab aula: / 'Non te, virgo, rogo, perturbent talia verba, / Istę percerte quia vatum more locutę / Iam nunc presaga dicebant voce futura, / Tu quia sola potenter eris regina perennis / Necnon stelligeri dominatrix inclita celi", Hrotsvit, Maria, w: Hrotsvit, Opera Omnia, s. 21-22 (cytat: s. 22).

73 Bliskie sobie ikonograficznie przedstawienia znajdują się w ewangelistarzu z Salzburga lub Reichenau (Monachium, Bayerische Staatsbibliothek, Clm 15713, fol. $1 v$ ) oraz w lekcjonarzu z Salzburga (Nowy Jork, Pierpont Morgan Library, Glazier Ms. 44, fol. 2r). Na ich temat patrz: J. Ott, Krone und Krönung. Die Verheißung und Verleihung 
tej właśnie, popularnej historii możemy znaleźć też w przedstawieniach Marii jako królowej w kontekście konkretnej wspólnoty konsekrowanych dziewic. Wydaje się, że z taką właśnie sytuacją mamy do czynienia w wypadku pochodzącego z Fuldy, ale zamówionego dla Essen, zaginionego kodeksu z żywotem świętych Kosmy i Damiana, współpatronów tego ostatniego opactwa. Na pochodzącym z XVIII w. szkicu, powstałym z kolei na podstawie kopii z końca XVI w. ${ }^{74}$, przedstawiającym znajdującą się w kodeksie scenę dedykacyjną, widzimy zasiadającą na tronie, ukoronowaną diademem i dzierżącą krzyż Marię Pannę podpisaną greckim napisem Theotekos (sic!). U jej stóp klęczy opatka Essen, Hadwiga, obok której stoi jeszcze jedna kanoniczka. Nieco wyżej widzimy św. Pinozę, której relikwie sprowadzono do Essen właśnie za rządów wspomnianej przed chwila ksieni ${ }^{75}$; tekst informuje, że opatka prosi „dziewicę Pinozę” o wstawiennictwo u Marii Panny ${ }^{76}$. Tymczasem nad tą ostatnią znajduje się następujący napis: „Oto krzyż drogiego Syna trzyma najlepsza Matka /

von Kronen in der Kunst von der Spätantike bis um 1200 und die geistige Auslegung der Krone, Mainz am Rhein 1998, s. 74, 148-149 oraz nr 127 i 133, s. 290-291. Datacja i proweniencja kodeksu Clm 15713 por. H. Hoffmann, Buchkunst und Königtum im ottonischen und frühsalischen Reich, Textband, Stuttgart 1986, s. 294-295; omawiane przedstawienie z tego kodeksu w kontekście tradycji ikonograficznej Praesentatio Mariae patrz: F. Machilek, M. Machilek, Zur Feier des Festes der Praesentatio Mariae und zur Ikonographie des Tempelgangs Marias, „Beiträge zur fränkischen Kunstgeschichte” 1-2, 1995-1996, s. 100-102. Datacja i proweniencja kodeksu Glazier Ms. 44 na stronie Pierpont Morgan Library https://www.themorgan.org/manuscript/76981 (dostęp: 29 VI 2018). Więcej o tradycji ikonograficznej tak oddania Marii Panny do świątyni, jak i jej życia w świątyni patrz: J. Lafontaine-Dosogne, Iconographie de l'enfance de la Vierge dans l'Empire byzantin et en Occident, Bruxelles 1965 (przedruk: 1992), s. 112-134. Lafontaine-Dosogne odnosi się również do interesującej nas sceny z Clm 15713, w której widzi najstarszą aluzję do życia Marii w świątyni w sztuce zachodniej, z tym że scenę koronacji przez anioła komentuje słowami: „un ange, qui descend des nuages en portant un object rond, probablement un pain", s. 130; pomysł, aby w rękach anioła zamiast korony zobaczyć chleb, to ewidentne nieporozumienie, por. F. Machilek, M. Machilek, op. cit., s. 102.

${ }^{74}$ Szkic znajduje się w spuściźnie osiemnastowiecznego scholastyka z Vreden, Jodokusa Hermanna Nünninga, obecnie w Archive von und zur Mühlen auf Haus Ruhr; patrz: Th. Rensing, Zwei ottonische Kunstwerke des Essener Münsterschatzes, „Westfalen. Hefte für Geschichte, Kunst und Volkskunde" 40, 1962, 1-2, s. 44-45; H. Schnitzler, Ein frühottonisches Fuldaer Kunstwerk des Essener Münsterschatzes, w: Studien zur Buchmalerei und Goldschmiedekunst des Mittelalters. Festschrift für Karl Hermann Usener zum 60. Geburtstag am 19. August 1965, red. F. Dettweiler, H. Köllner, P.A. Riedl, Marburg 1967, s. 115; R. Kahsnitz, The Gospel Book, cz. 1, s. 145.

${ }^{75}$ T. Rensing, op. cit., s. 47; H. Schnitzler, Ein frühottonisches, s. 117-118; R. Kahsnitz, The Gospel Book, cz. 1, s. 145.

76 „Hic supplex Hadauuih Pinnosae virginis almu(m) / Postulat auxiliu(m), per q(uo)d salvet(ur) in aevu(m) / Et sibi placata(m) XPI faciat genitricem". Tekst por. MGH, Poetae, t. 5, 3, wyd. G. Silagi, München 1979, s. 675. 
którą chór anielski prawnie uznał za królową"77. Zgromadzenie dziewic, reprezentowane przez opatkę i świętą patronkę, oddaje się więc w opiekę Marii Pannie, której królewski status, także jako królowej dziewic właśnie, ogłoszony został przez anioły.

\section{Maria Panna koronująca}

W niezachowanym kodeksie dla Essen znajdowało się jeszcze jedno wyobrażenie, które także dotarło do nas w postaci szkicu. Oto w żywocie braci męczenników, a zarazem patronów opactwa, Kosmy i Damiana, przedstawieni oni zostali $\mathrm{z}$ dwóch stron umieszczonego $\mathrm{w}$ mandorli Chrystusa, który nakłada na ich głowy korony - nagrodę za poniesione męczeństwo ${ }^{78}$. Nabiera ono z naszego punktu widzenia znaczenia dopiero w powiązaniu z inną sceną, której ikonograficzne pokrewieństwo nie może budzić wątpliwości. Chodzi mianowicie o koronację świętych Małgorzaty i Reginy ${ }^{79}$ (il. 5) w kodeksie także pochodzącym z Fuldy ${ }^{80}$ i datowanym ostrożnie na lata $965-1000^{81}$, a zawierającym żywot tej pierwszej świętej poprzedzony żywotem św. Kiliana. O ile jednak w przywołanej przed chwilą scenie Kosmę i Damiana koronuje Zbawiciel, tronująca i sama nosząca koronę postać, która koronuje święte dziewice męczennice, mimo podobieństw do Chrystusa ${ }^{82}$, podpisana jest Theotekos (sic!).

Nie można wykluczyć, że dwa omawiane tu kodeksy są paralelne Cynthia Hahn przypuszcza, że brakująca, pierwsza karta pasji św. Kiliana i pasji św. Małgorzaty zawierała przedstawienie analogiczne do tego ze św. Pinozą, Hadwigą i Marią Panną ${ }^{83}$. To jednak jedynie domysły, podobnie jak i to, że sam kodeks mógł być przeznaczony dla Essen ${ }^{84}$, choć są

77 „Ecce cruce $(\mathrm{m})$ cari mate(r) tenet optima nati, / Qua(m) chorus angelic(us) regina(m) iure fatetur". Tekst por. MGH, Poetae, t. 5, 3, s. 674.

78 O koronie żywota wiecznego patrz przede wszystkim: J. Ott, op. cit., zwł. s. 168210; L. Körntgen, Königsherrschaft und Gottes Gnade. Zu Kontext und Funktion sakraler Vorstellungen in Historiographie und Bildzeugnissen der ottonisch-frühsalischen Zeit, Berlin 2001, s. 279-282; R. Kahsnitz, Coronas aureas in capite. Zum Allerheiligenbild des Reichenauer Kollekrats in Hildesheim, w: Per assiduum studium Scientiae Adipisci Margaritam. Festgabe für Ursula Nilgen zum 65. Geburtstag, red. A. Amberger, St. Ottilien 1997, s. 61-96 (passim).

${ }^{79}$ Hannover, Niedersächsische Landesbibliothek Ms. I 189, fol. 11v.

80 Patrz: C.J. Hahn, Passio Kiliani. Ps. Theotimus, Passio Margaretae. Orationes. Kommentarbar, Graz 1988, s. 27, gdzie dalsza literatura przedmiotu.

${ }^{81}$ Ibidem, s. 27-28.

82 Por. K.M. Collins, op. cit., s. 92-93; R. Kahsnitz, The Gospel Book, „Bulletin of the John Rylands Library" 53, 1970-1971, 2, s. 378.

${ }^{83}$ C.J. Hahn, op. cit., s. 99-101.

${ }^{84}$ Ibidem, s. 134-138. 
przesłanki, aby uważać, że faktycznie powstał na zamówienie żeńskiego klasztoru, względnie jakiejś kobiety ${ }^{85}$. Najważniejszy jest jednak dla nas fakt, że o ile męczenników koronuje Chrystus, święte dziewice otrzymują swe korony od Marii Panny.

Trudno uznać to za przypadek. Zauważyć trzeba bowiem, że obie sceny - choć, jak wskazywano, podobne w pewnym stopniu do bizantyńskich wyobrażeń koronacji cesarskiej pary przez Chrystusa - wpisują się przede wszystkim w tradycję ikonograficzną prezentującą koronacje świętych. Można tu przywołać przykłady takie jak przedstawienia św. św. Piotra i Pawła czy św. św. Wiktora i Gereona ${ }^{86}$. Tyle tylko, że we wszystkich tych przypadkach koronującym jest zawsze Chrystus - koronacja przez Marię Pannę jest zupełnie wyjątkowa ${ }^{87}$.

Uwagę zwraca jeszcze jedna kwestia. Jak zauważa Hahn, o ile Kosma i Damian byli braćmi i wspólnie ponieśli męczeństwo, Piotr i Paweł także byli ze sobą blisko powiązani, o tyle Wiktora i Gereona łączyło to, że należeli do jednego legionu, a w istocie - że obaj to święci żołnierze. Chodzi więc o podział świętych na kategorie i to właśnie tłumaczy też powiązanie Małgorzaty z Reginą. Podkreślmy bowiem, że żywot tej drugiej w kodeksie się nie znalazł, choć przypuszczano, że miniatura może być wzorowana na jakimś innym kodeksie, w którym były żywoty obu świętych $^{88}$. Regina jest więc dodana do sceny koronacji, jak stwierdził Theodor Rensing ${ }^{89}$, raczej ze względu na tradycję ikonograficzną, z potrzeby symetrii. Ale nie jest to przecież wybór przypadkowy - żywoty obu świętych były w zasadzie paralelne, jeden stanowił zapewne zresztą dla drugiego wzór ${ }^{90}$, w obu też wypadkach chodziło o święte dziewice. Właśnie jako takie były one przecież znane, a dziewictwo Małgorzaty to cecha wyraźnie uwypuklona w jej żywocie, który prezentuje nam kodeks o ile Kilian występuje tu jako martyr, ona nazywana jest virgo. To właśnie ono zadecydowało o powiązaniu dwóch świętych kobiet, a także o decyzji, aby koronacji dokonywała Maria Panna - stwierdza Hahn, przywołując jako analogię jedenastowieczną miniaturę z St. Bertin z medalionem przedstawiającym Marię Pannę jako królową w otoczeniu dwóch dziewic. Badaczka konkluduje: „Dziewica Maria wita Małgorzatę i Reginę

85 Ibidem, s. 133-135.

86 T. Rensing, op. cit., s. 52; C.J. Hahn, op. cit., s. 100-102; J. Ott, op. cit., s. 112-114.

87 C.J. Hahn, op. cit., s. 103.

${ }^{88} \mathrm{~J}$. Weitzmann-Fiedler, Zur Illustration der Margaretenlegende, „Münchner Jahrbuch der bildenden Kunst" 17, 1966, s. 30.

${ }^{89}$ T. Rensing, op. cit., s. 53.

90 C.J. Hahn, op. cit., s. 102-103; J. Weitzmann-Fiedler, op. cit., s. 30 wraz z przyp. 52 (s. 48). 
w chórze dziewic, w którym status i kategoria zastępują indywidualność

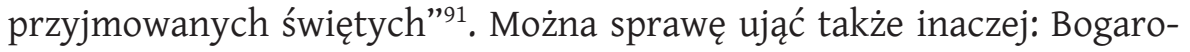
dzica nie tylko sama zawdzięcza swój królewski status i władzę dziewictwu, ale jest też tą, która udziela nagrody za dziewicze życie w postaci niebiańskiej korony.

Mówiąc o koronującej Marii Pannie, trzeba koniecznie przywołać jeszcze jedną scenę. Mam na myśli jedno z wyobrażeń na cyborium w bazylice św. Ambrożego w Mediolanie. Na jego stronie wschodniej i zachodniej znajdują się przedstawienia odpowiednio Chrystusa ze św. św. Piotrem i Pawłem oraz najpewniej św. Ambrożego w otoczeniu św. św. Gerwazego i Protazego, przyjmującego hołd od dwóch duchownych. Część południową zajmuje natomiast wyobrażenie dwóch brodatych mężczyzn z koronami na głowach, zapewne władców, składających hołd świętemu biskupowi, natomiast w części północnej widzimy dwie kobiety, jedną koronowaną, drugą nie, oddające hołd Marii Pannie ${ }^{92}$. O ile identyfikacja Bogarodzicy nie wzbudziła specjalnych wątpliwości i wydaje się solidnie ugruntowana ${ }^{93}$, to w wypadku pozostałych odbierających hołd świętych sprawa jest bardziej problematyczna. Tak bowiem ten w stroju biskupim, jak i ten, którego określiłem - zgodnie z większością badań - jako najpewniej św. Ambrożego, byli utożsamiani i ze św. Ambrożym, i ze św. Benedyktem, padały też i inne propozycje ${ }^{94}$.

Jeszcze większe wątpliwości wiążą się z identyfikacją postaci oddających świętym hołd, zwłaszcza dwóch mężczyzn z brodami, oraz dwóch kobiet skłaniających się przed Marią Panną. Mimo rozmaitych propozycji ${ }^{95}$, obecnie większość badaczy zdaje się zgadzać z tym, że możemy

91 „The Virgin welcomes Margaret and Regina to the choir of virgins and the saint's status and class supersede her individuality", C.J. Hahn, op. cit., s. 102-103 (cytat: s. 103).

${ }^{2}$ C. Nordenfalk, Milano e l'arte ottoniana. Problemi di fondo signora poco osservati, w: Il millennio ambrosiano. La città del vescovo dai Carolingi al Barbarossa, red. C. Bertelli, Milano 1988, s. 102.

93 G. Bognetti, C. Marcora, L'abbazia benedettina di Civate. Note di storia e di arte, Civate 1957, s. 118; A. Peroni, La plastica in stucco nel. S. Ambrogio di Milano. Arte ottoniana e romanica in Lombardia, w: Kolloquium über Spätantike und frühmittelalterliche Skulptur, t. 3, red. V. Milojčić, Mainz 1974, s. 88; P.A. Mariaux, op. cit., s. 206; C. Nordenfalk, op. cit., s. 102; P. Corbet, Les impératrices ottoniennes, s. 116. Jedynie Sandro Chierici Lombardie romane, La-Pierre-qui-Vire 1978 (oryg. wł. 1978), s. 92 widział w postaci św. Scholastykę.

94 Por. A. Peroni, op. cit., s. 85-87; C. Nordenfalk, op. cit., s. 102; P. Corbet, Les impératrices ottoniennes, s. 116; G. Bognetti, C. Marcora, op. cit., s. 118-119; S. Chierici, loc. cit.

${ }^{95}$ Możliwe identyfikacje z postaciami z wieku X i XI przytaczają: P.E. Schramm, Die deutschen Kaiser und Könige in Bildern ihrer Zeit 751-1190, München 1983, nr 86, s. 189-190, a za nim P. Corbet, Les impératrices ottoniennes, s. 116. W istocie badacze proponowali 
rozpoznać w nich Ottona I i Ottona II oraz Adelajdę i Teofano ${ }^{96}$. Identyfikacja tej ostatniej wiąże się z tezą Percy'ego Schramma, który na podstawie braku korony na jej głowie proponuje datować zabytek na okolice roku 972, kiedy to, w kwietniu, Bizantyjka poślubiła Ottona II i została dopiero koronowana ${ }^{97}$. Warto zresztą w tym miejscu zwrócić uwagę na koronę, którą dzierży w dłoni Maria Panna - czy nie jest przypadkiem tak, jak sugerował Adriano Peroni, że jest ona przeznaczona właśnie dla nowej cesarzowej, a cała scena ma nawiązywać do niedawnej koronacji Teofano? ${ }^{98}$

W świetle sceny z koronacją św. św. Małgorzaty i Reginy przez Marię Pannę możliwa jest i inna interpretacja, a mianowicie, że przynajmniej jedna z postaci jest konsekrowaną dziewicą, która otrzymuje właśnie swą nagrodę; korona byłaby tu rozumiana w sensie eschatologicznym, jako korona żywota wiecznego ${ }^{99}$. Tego rodzaju rozumienie sceny wzmacnia fakt pomijany często przez badaczy identyfikujących postać z cesarzową, a mianowicie takie właśnie, eschatologiczne rozumienie przynajmniej niektórych z koron przedstawionych na cyborium. Oto bowiem manus Dei spuszcza koronę także na głowę św. biskupa, któremu hołd oddają dwaj świeccy, koronowany jest także przyjmujący hołd od duchownych św. Ambroży (?); obaj święci mają jednocześnie aureole. Więcej: ten ostatni trzyma w ręku koronę, przeznaczoną najwyraźniej dla jednego $\mathrm{z}$ duchownych $-\mathrm{w}$ tym wypadku jest to z pewnością symbol nagrody, być może przeznaczonej dla postaci stojącej po jego prawicy, jak chciał Peroni ${ }^{100}$ - arcybiskupa mediolańskiego, a zarazem fundatora cyborium, którego model prezentuje on świętemu.

Tym tropem szedł w swych rozważaniach Gianpiero Bognetti, który uważał, że widzimy tu rodzinę ottońską, z tym że dwaj duchowni to brat i syn Ottona I, a więc odpowiednio: arcybiskupi koloński Bruno i moguncki - Wilhelm, podczas gdy kobiety to Adelajda, ale nie

jednak rozmaite datacje zabytku, od IX do XII-XIII w. (sic!), które przytacza w odniesieniu do starszych badań Géza de Francovich, Arte carolingia ed ottoniana in Lombardia, „Römisches Jahrbuch für Kunstgeschichte” 6, 1942-1944, s. 116-118, przyp. 2. Sam badacz opowiadał się za dziewiątowieczną datacją zabytku.

96 Tak: P.E. Schramm, Die deutschen Kaiser, nr 86, s. 189-190; A. Peroni, op. cit., s. 82-104, zwł. s. 91; Ch.T. Little, Avori milanesi del X secolo, w: Il millennio ambrosiano, s. 88; P. Corbet, Les impératrices ottoniennes, s. 116-117. Podobnie: C. Nordenfalk, op. cit., s. 102.

97 P.E. Schramm, Die deutschen Kaiser, nr 86, s. 190. Por. P. Corbet, Les impératrices ottoniennes, s. 116.

98 A. Peroni, op. cit., s. 91.

99 O koronie żywota por. wyżej, przyp. 78.

100 A. Peroni, op. cit., s. 85-86. 
w towarzystwie Teofano, ale Matyldy, opatki Kwedlinburga ${ }^{101}$. Zdaniem badacza, korony w rękach Marii Panny i św. Ambrożego miały być aluzją do wstąpienia niektórych członków rodu ottońskiego w stan duchowny ${ }^{102}$. Zważywszy jednak na kontekst w postaci koron na głowach świętych z cyborium, a także szerszą tradycję ikonograficzną omówioną wyżej, z taką interpretacją można by się zgodzić tylko o tyle, o ile przystąpienie do stanu duchownego, a więc i stanu dziewiczego, rozumiałoby się jako pierwszy krok na drodze do uświęcenia. Zauważmy zresztą, że gdyby chcieć koronę wiązać konkretnie z dziewictwem, to mogłaby ona przypaść nie tylko arcybiskupowi fundatorowi, ale i drugiemu z mnichów, w interpretacji Peroniego - opatowi klasztoru benedyktyńskiego znajdującego się przy mediolańskiej katedrze ${ }^{103}$. Tak czy inaczej, abstrahując już od prób konkretnej identyfikacji postaci z cyborium, stwierdzić należy, że w świetle tradycji ikonograficznej kobieca postać, która ma otrzymać koronę od Marii Panny, może wcale nie być władczynią, a właśnie konsekrowaną dziewicą.

\section{Władczyni i święte dziewictwo}

Należy jednak zauważyć, że eschatologiczne rozumienie przedstawionej na mediolańskim cyborium sceny otrzymywania przez żeńską postać korony z rąk Marii Panny i wiązanie tej ostatniej z dziewictwem niekoniecznie musi też wykluczać, że mamy tu do czynienia z władczynią. W jakimś bowiem sensie - jak pokażę - ją także traktowano jak dziewicę, mogła więc oczekiwać podobnej do dziewic nagrody.

Wprost mówi o tym ordo koronacyjne królowej znane jako Ordo III ${ }^{104}$. Nakładaniu korony, który to moment w sensie teologicznym ściśle wiązał

101 G. Bognetti, C. Marcora, op. cit., s. 119. Bognetti pisze o Matyldzie „futura badessa di Quedlinburg", co jednak nie odpowiada jego własnej propozycji datacji dzieła jako powstałego po roku 972; Matylda została ksienią Kwedlinburga już w roku 966.

102 Ibidem.

103 A. Peroni, op. cit., s. 86-88.

104 Ordo zostało opublikowane pod tytułem Benedictio reginae najpierw w Die Ordines für die Weihe und Krönung des Kaisers und der Kaiserin. Ordines coronationis imperialis, wyd. R. Elze, MGH Fontes 9, Hannover 1960, III, s. 6-9, następnie zaś w Le pontifical romano-germanique du dixième siècle, wyd. C. Vogel, R. Elze, Città del Vaticano 1963, t. 1, nr LXXVIII, s. 267-269, z którego to wydania będę korzystał. Tradycyjna datacja ordo, które wiązano z koronacją Adelajdy i powstaniem tzw. Pontyfikału Rzymsko-Niemieckiego w latach sześćdziesiątych X w., stała się ostatnio mocno problematyczna. Trudno wszelako przedatować ten tekst na okres późniejszy niż początki wieku XI, co z naszego punktu widzenia jest datacją wystarczającą, aby uznać go za oddający sposób myślenia interesującej nas epoki. Całość problemu wyczerpująco przestawia Simon MacLean, 
się z symbolizowaną przez koronę żywota wiecznego nagrodą w Niebie ${ }^{105}$, towarzyszy tu modlitwa, aby królowa po śmierci wyszła naprzeciw Wiecznego Oblubieńca Jezusa Chrystusa w towarzystwie roztropnych dziewic ${ }^{106}$. W analogicznym fragmencie dotyczącym władcy mowa jest jedynie o przyjęciu do chwały nieba inter gloriosos athletas ${ }^{107}$. W tekście błogosławieństwa królowej jest jednak fragment, który jeszcze bardziej jednoznacznie odnosi władczynię do dziewic, których świętość jest dla niej punktem odniesienia, ponownie zresztą przywołując w tym kontekście symbol palmy. Czytamy więc: „Błagamy [--] aby w królewskim małżeństwie zawsze pozostając skromną (pudica), zdołała zachować palmę bliską dziewiczej"108. Zdanie to jest także trawestowane w Vita Mathildis posterior, gdzie mowa jest tak o zachowywaniu w małżeństwie palmy bliskiej dziewiczej $^{109}$, jak i - w innym miejscu - o uzyskiwaniu przez świętą królową

Ottonian Queenship, Oxford 2017, s. 183-197, który sam proponuje, aby wiązać powstanie tekstu z koronacją królewską Kunegundy w roku 1002. Szerzej na temat problemów związanych z tzw. Pontyfikałem Rzymsko-Niemieckim por. H. Parkes, The Making of Liturgy in the Ottonian Church. Books, Music and Ritual in Mainz, 950-1050, Cambridge 2015. Analiza tekstu ordo por. F.-R. Erkens, „Sicut Esther regina”. Die westfränkische Königin als „consors regni”, „Francia” 20, 1993, 1, s. 24-25; A. Sprengler-Ruppenthal, Zur Theologie des consors-regni Formel in der sächsischen Königs- und Kaiserzeit, „Jahrbuch des Gesellschaft für niedersächsische Kirchengeschichte" 83, 1985 (= Festschrift zum 65. Geburtstag von Landessuperintendent i. R. Dr. Kurt Schmidt-Clausen, Abt von Amelungsborn, red. H.-W. Krumweide), s. 93-100; J.L. Nelson, Early Medieval Rites of Queen-Making and the Shaping of Medieval Queenship, w: Queens and Queenship, s. 311-312; S. MacLean, Ottonian Queenship, s. 184-186; G. Pac, Koronacje władczyń we wcześniejszym średniowieczu - zarys problematyki, w: Gnieźnieńskie koronacje królewskie i ich środkowoeuropejskie konteksty, red. J. Dobosz, M. Matla, L. Wetesko, Gniezno 2011, s. 49-52.

105 Por. J. Ott, op. cit., zwł. s. 211-219; L. Körntgen, op. cit., zwł. s. 281, a ostatnio P. Figurski, Das sakramentale Herrscherbild, s. 157.

106 „Post occasum huius saeculi, cum prudentibus virginibus sponso perenni domino nostro Iesu Christo, digne et laudabuliter occurrens, regiam caelestis aulae merearis ingredi ianuam", Le pontifical romano-germanique, t. 1, nr LXXVIII, s. 269. Por. N. Gussone, Trauung und Krönung. Zur Hochzeit der byzantinischen Prinzessin Theophanu mit Kaiser Otto II., w: Kaiserin Theophanu. Begegnung des Ostens und Westens um die Wende des ersten Jahrtausends, t. 2, red. A. von Euw, P. Schreiner, Köln 1991, s. 171-172; P. Corbet, Les impératrices ottoniennes, s. 111-112; A. Sprengler-Ruppenthal, op. cit., s. 100.

107 Le pontifical romano-germanique, t. 1, nr LXXII, s. 257.

108 „Exoramus [--] ut, in regalis foedere coniugii semper manens pudica, proximam virginitati palmam continere queat", Le pontifical romano-germanique, t. 1, nr LXXVIII, s. 268. Słowa te są $\mathrm{w}$ istocie cytatem $\mathrm{z}$ dość znanego we wczesnym średniowieczu tekstu, a mianowcie Epistola ad Macedonium, w: Sedulii opera omnia, wyd. I. Huemer, Wien 2007 (CSEL, 10; wyd. 1 1885), s. 10. Por. P. Corbet, Les saints ottoniens. Sainteté dynastique, sainteté royale et sainteté féminine autour de l'an Mil, Sigmaringen 1986, s. 187; N. Gussone, loc. cit.; S. MacLean, Ottonian Queenship, s. 197-198 wraz z przyp. 82.

109 „In coniugii federe manebat pudica et tamen nichilominus caruit palma virginitati proxima", Vita Mathildis reginae posterior, wyd. B. Schütte, MGH SrG in usum scholarum, t. 66, Hannover 1994, cap. 5, s. 153. 
nagrody bliskiej tej dziewiczej ${ }^{110}$. Tekst ten słusznie uchodzi za swoiste zwierciadło, doskonale oddające ideał ottońskiej władczyni ${ }^{111}$, a cytowane tu zdanie, podobnie jak i analogiczny fragment z ordo, jasno wskazują na wagę, jaką miała idea świętego dziewictwa dla kształtowania religijnego rozumienia postaci królowej.

Powiązanie władczyń z dziewicami, także świętymi dziewicami, wydaje się mocne i wyraźnie zaznacza się w tekstach ściśle związanych z samą istotą rozumienia ich roli jako cesarzowych czy królowych. Mam tu na myśli, obok ordines, także i laudes regiae. W jednym z najstarszych znanych nam tekstów tego rodzaju żonie Karola Wielkiego, Fastradzie, towarzyszy więc właśnie wezwanie virgines $C h r i s t i^{112}$. W późniejszych tekstach z obszaru karolińskiego, o ile małżonka władcy w ogóle się pojawia, towarzyszą jej niemal zawsze święte z chóru dziewic, takie jak Perpetua i Felicyta, Agata, Łucja, Cecylia czy Agnieszka ${ }^{113}$. Podobnie rzecz wygląda w tekstach z obszaru Rzeszy, z okresu rządów Liudolfingów ${ }^{114}$.

110 „Non ergo est dubitandum, quin dei gratia nunc perceperint praemium virginitati proximum, quia in ipsis regnavit castitas coniugalis, nec tamen defuit continentia laudabilis", Vita Mathildis reginae posterior, cap. 6, s. 156-157. Por. P. Corbet, Les saints ottoniens, s. 184-191.

111 P. Corbet, Les saints ottoniens, zwł. s. 155-234. A.C. Stinehart, „Renowned Queen Mother Mathilda". Ideals and Realities of Ottonian Queenship in the Vitae Mathildis reginae (Mathilda of Saxony, 895?-968), „Essays in History” 40, 1998, http://www.essaysinhistory.com/renowned-queen-mother-mathilda-ideals-and-realities-of-ottonian-queenship-in-the-vitae-mathildis-reginae-mathilda-of-saxony-895-968/ (dostęp: 17 IX 2018).

112 „Exaudi Christe / Fastradae reginae salus et vita. / Alias virgines Christi, quales volueris”, B. Opfermann, Die liturgischen Herrscherakklamationen im Sacrum Imperium des Mittelalters, Weimar 1953, nr I,1, s. 101. Na temat innych wydań patrz: E.H. Kantorowicz, Laudes regiae. A Study in Liturgical Acclamations and Mediaeval Ruler Worship, Berkeley-Los Angeles 1958, s. 21, przyp. 19. Uważa się niekiedy, że jest to formuła koronacyjna Fastrady, por. ibidem, s. 21 wraz z przyp. 19, s. 37 wraz z przyp. 92; A. Gastoué, La musique d'Église. Études historiques, esthétiques et pratiques, Lyon 1911, s. 193. Na temat tekstu por. też A. Krüger, Litanei-Handschriften der Karolingerzeit, MGH, Hilfsmittel, t. 24, Hannover 2007, s. 78-90, gdzie dalsza literatura. Używam tu określenia „święte dziewice” czy za Ernstem H. Kantorowicznem (Laudes regiae, s. 62) „chór dziewic”, choć w grupie tej pojawiają się np. Perpetua, Felicyta czy Radegunda, a więc kobiety zamężne czy nawet posiadające dzieci. Ma to jednak swoje uzasadnienie w tym, jak klasyfikowano w litaniach święte kobiety, o czym więcej w dalszej części tekstu.

113 B. Opfermann, op. cit., nr I,4 (s. 104-105); I,5 (s. 106); I,6 (s. 109); I,8 (s. 112). Por. E.H. Kantorowicz, Laudes regiae, s. 62, 140. Wyjątkiem mogą tu być jedynie dwa niepełne teksty, zachowane w tym samym rękopisie i datowane przez wydawcę odpowiednio na lata 814-817 i 823-840, B. Opfermann, op. cit., nr II,2 i II,3 (s. 115).

114 B. Opfermann, op. cit., nr III,1 (s. 124); III,2 (s. 127); III,5 (s. 129); III,6 (s. 131); III,8 (s. 134); III,9 (s. 136). 
Dla pełnego obrazu dodać trzeba jeszcze oczywiste związki władczyń z klasztorami. Warto w tym kontekście przywołać postać zachodniofrankijskiej królowej, należącej zarazem do bezpośredniego kręgu ottońskiego, a mianowicie siostry Ottona I, Gerbergi. W skierowanym do niej liście dedykacyjnym dołączonym do traktatu De Antichristo jego autor, Adso, nazywa Gerbergę „matką mnichów i przywódczynią dziewic"115. Simon MacLean zwraca uwagę na widoczne w tym stwierdzeniu połączenie w osobie Gerbergi queenship i przywództwa monastycznego, przypominając, że także mnisi widzieli siebie - o czym była już mowa - jako dziewice ${ }^{116}$. Na ich czele stoi tu jednak nie Maria Panna, ale ziemska królowa.

Dodajmy jednak, że w ordo Bogarodzica, inaczej niż postaci starotestamentowych kobiet, nie występuje w funkcji wzoru dla królowej ${ }^{117}-$ pojawia się raczej marginalnie, choć zapewne nieprzypadkowo, przy wezwaniu Chrystusa, narodzonego „z niepokalanego łona świętej Marii Panny"118. Także Vita Mathildis posterior, skupione na problemie małżeńskiej castitas $^{119}$, wspomina o niej jedynie jako patronce Nordhausen; rzecz ma zresztą ścisły związek z macierzyństwem - Matylda poświęciła Bogarodzicy wspólnotę dziewic ufundowaną przez siebie w miejscu, gdzie dzięki jej wstawiennictwu dwukrotnie szczęśliwie urodziła ${ }^{120}$. Wreszcie w laudes Maria Panna towarzyszy zawsze władcy, przynajmniej gdy ten występuje sam ${ }^{121}$. Jeśli zaś pojawia się także jego małżonka - wezwanie

115 „Excellentissime regine ac regali dignitate pollenti, Deo dilecte omnibusque sanctis amabili, monachorum matri et sanctarum virginum duci, domine regine Gerberge", Adso, De ortu et tempore Antichristi. Necnon et tractatus qui ab eo dependunt, wyd. D. Verhelst, CCCM 45, Turnhout 1976, s. 20.

116 S. MacLean, Ottonian Queenship, s. 64-65; idem, Reform, Queenship, s. 656-657.

117 Por. D. Iogna-Prat, La Vierge et les „ordines” de couronnement des reines au IXe siècle, w: Marie. Le culte de la Vierge, s. 107.

118 „Per Christum dominum rostrum, qui ex intemerato beate Mariae virginis alvo nasci", Le pontifical romano-germanique, t. 1, nr LXXVIII, s. 268.

119 P. Corbet, Les saints ottoniens, s. 184-191; G. Pac, Obraz małżeństwa w wybranych niemieckich źródłach hagiograficznych X $i$ XI wieku, w: Kult świętych i ideat świętości w średniowieczu, red. R. Michałowski, Warszawa 2011, s. 47-69.

${ }^{120}$ Vita Mathildis reginae posterior, cap. 22, s. 298. Por. P. Corbet, Les impératrices ottoniennes, zwł. s. 122-123; K.J. Leyser, Rule and Conflict in an Early Medieval Society. Ottonian Saxony, London 1979, s. 67. O związku Marii Panny z macierzyństwem władczyni i jej opieką nad dynastią por. też E.-D. Hehl, op. cit., s. 282-291.

${ }^{121}$ Maria Panna pojawia się w: B. Opfermann, op. cit., I,7 (s. 110); II,1 (s. 114); II,4 (s. 116); II,5 (s. 118); III,7 (s. 132) - w tym ostatnim dziewice zwykle występujące przy władczyni pojawiają się po wezwaniu: „Exaudi Christe / Antistiti a Deo electo vita et victoria” (s. 132-133). Por. E. Kantorowicz, Ivories and Litanies, „Journal of the Warburg and Courtauld Institutes" 5, 1942, zwł. s. 60-61, 68-73. 
Marii bywa przenoszone do części jej dotyczącej ${ }^{122}$. Często jednak albo nadal towarzyszy ona jedynie władcy ${ }^{123}$, albo też pojawia się podwójnie - raz w modlitwie za cesarza, drugi raz, jako pierwsza w grupie świętych kobiet, w modlitwie za cesarzową ${ }^{124}$. W kontekście władczyni zatem, Maria Panna, o ile w ogóle występuje, przywoływana jest zawsze w towarzystwie świętych dziewic, które - jak pamiętamy - są wzywane jako opiekunki królowej, ilekroć ta w aklamacjach się pojawia.

Władczyni związana jest więc przede wszystkim ze świętym dziewictwem, a dopiero za jego pośrednictwem - z pierwszą spośród dziewic, Marią Panną. To właśnie święte dziewice przywoływane są w modlitwach za nią, to idea dziewictwa stawiana jest jej za wzór, w momencie kluczowym dla jej władzy, a więc gdy uzyskuje królewską koronę. Wreszcie sama jej władza jest ściśle związana z konsekrowanym dziewictwem, jako że - jak zauważa Simon MacLean - „kontrolowanie [żeńskich - G.P.] opactw stało się charakterystyczną cechą bardziej zinstytucjonalizowanych form pełnienia funkcji królowej (queenship), które wytworzyły się w X w. w królestwach będących następcami królestw karolińskich", co odnosi on także do władczyń ottońskich, do których pozycji ex officio przypisano nadzór nad poszczególnymi klasztorami ${ }^{125}$.

Koncepcja, że to właśnie dziewice są szczególnymi opiekunkami władczyni, a ona sama z dziewictwem winna być powiązana, jest więc w myśli politycznej tego okresu wyraźna i tłumaczy też - częściej pośrednie, niż bezpośrednie - związki cesarzowej z Marią Panną. W tym wypadku mamy niewątpliwie do czynienia z ideą związaną z podziałami

122 B. Opfermann, op. cit., nr I,4 (s. 104-105); III,1 (s. 124); III,2 (s. 127); III,8 (s. 134). Por. E.H. Kantorowicz, Laudes regiae, s. 44, przyp. 112; idem, s. 60-61.

123 B. Opfermann, op. cit., nr III,5 (s. 129); III,6 (s. 131). Por. E.H. Kantorowicz, Laudes regiae, s. 44, przyp. 112. Trudno zgodzić się zatem z opinią Patricka Corbeta (Les impératrices ottoniennes, s. 133 wraz z przyp. 97), który uważa występowanie Marii Panny przy osobie cesarza, a nie cesarzowej w laudes począwszy od roku $1000 \mathrm{za}$ rzecz wyjątkową.

${ }^{124}$ B. Opfermann, op. cit., I,6 (s. 109); I,8 (s. 111-112); III,9 (s. 136). Por. uwagi Felice Lifshitz (op. cit., s. 93-95), że w litaniach do świętych Maria Panna, choć jej związek z dziewicami nie może budzić wątpliwości, pojawia się jednak nie wraz z nimi, a na początku całej listy świętych, jest więc od samej grupy virgines oddzielona.

125 „The control of abbeys became a characteristic feature of the more institutionalized forms of queenship which developed in the Carolingian successor kingdoms of the tenth century", S. MacLean, Queenship, Nunneries and Royal Widowhood in Carolingian Europe, „Past \& Present” 178, 2003, s. 36-37 (cytat: s. 36). Por. G. Althoff, Probleme um die dos der Königinnen im 10. und 11. Jahrhundert, w: Veuves et veuvage dans le haut Moyen Âge, red. M. Parisse, Paris 1993, s. 123-132 (passim). Zauważmy jednak, że przekazywanie tych samych ziem jako wiana kolejnym kobietom wchodzącym do rodu było zjawiskiem częstym i bynajmniej nie dotyczyło jedynie klasztorów. 
o charakterze płciowym, co bardzo wyraźnie widać było w wypadku przywołanych tu nawiązań do dziewictwa w ordo królowej, nieobecnych rzecz jasna - w ordo króla. Wynika to z powiązania z władczynią cnót dotyczących życia seksualnego, co ma związek z jej funkcją jako matki królewskich dzieci ${ }^{126}$. Jaką zaś rolę mogły odgrywać właściwe zachowania seksualne kobiet (lub ich brak) dla legitymizacji dynastycznej w kręgu Ottonów, pokazuje chyba najlepiej przeciwstawienie „włoskich dziwek i niemieckich matron" w Antapodosis Liutpranda ${ }^{127}$. Znaczenie czystości władczyni idzie zresztą dalej: jak pokazuje Geneviève Bührer-Thierry w tekście poświęconym oskarżeniom karolińskich władczyń o zdradę, ponieważ porządek w rodzinie królewskiej odzwierciedla i konstytuuje zarazem porządek kosmiczny i porządek w królestwie, brak czystości w małżeństwie królewskim - na straży której stoi właśnie królowa - czy zdrada władczyni wiążą się ściśle z confusio regni, a więc stanem nieporządku w państwie ${ }^{128}$.

\section{Podsumowanie}

O ile w odniesieniu do władczyni uwypuklanie znaczenia dziewictwa jest niewątpliwie związane $\mathrm{z}$ płcią, to $\mathrm{w}$ szerszej perspektywie sprawa przestaje być tak jednoznaczna. $\mathrm{Z}$ jednej bowiem strony jako dziewice mogą postrzegać się - jak widzieliśmy - tak mniszki i kanoniczki, jak i mnisi czy biskupi i z tym właśnie wiązać swą cześć dla Bogarodzicy. Z drugiej - trudno jednak nie odnieść wrażenia, że w wypadku tych pierwszych rzecz nabiera, być może poprzez znaczenie motywu oblubieństwa z Chrystusem, szczególnego znaczenia. Jak komentowali zdanie o osiągnięciu przez królową Matyldę palmy bliskiej dziewiczej Lothar Bornscheuer i Patrick Corbet ${ }^{129}$, virginitas jawi się tu jako wyższy rodzaj świętości, wydaje się jednak - dodam od siebie - że przede wszystkim

126 Por. P. Corbet, Les impératrices ottoniennes, zwł. s. 122-123. O znaczeniu cnoty czystości dla władczyni por. też G. Pac, Genitrix Iudith nomine. Judyta Czeska i jej miejsce w Kronice Galla Anonima na tle porównawczym, w: Christianitas Romana, zwł. s. 143-146.

$127 \mathrm{Ph}$. Buc, Italian Hussies and German Matrons. Liutprand of Cremona on Dynastic Legitimacy, „Frühmittelalterliche Studien” 29, 1995, s. 207-225 (passim).

${ }^{128}$ G. Bührer-Thierry, La reine adultère, „Cahiers de civilisation médiévale X $\mathrm{X}^{\mathrm{e}}-\mathrm{XII}{ }^{\mathrm{e}}$ siècles” 35, 1992, 4, zwł. s. 299-305. Por. J.M.H. Smith, Gender and Ideology in the Early Middle Ages, w: Gender and Christian Religion, red. R.N. Swanson, Woodbridge 1998, s. 70-71.

129 L. Bornscheuer, Miseriae regum. Untersuchungen zum Krisen- und Todesgedanken in der herrschaftstheologischen Vorstellung der ottonisch-salischen Zeit, Berlin 1968, s. 72 wraz z przyp 372; P. Corbet, Les saints ottoniens, s. 136. 
świętości kobiecej i właśnie dlatego stanowi punkt odniesienia także dla królowej.

Wpisuje się to zresztą w pewien sposób rozumienia kobiecej świętości w średniowieczu. Nie przypadkiem przecież w omawianym wyżej kodeksie Kilian określany jest jako męczennik, Małgorzacie natomiast - także przecież męczennicy - towarzyszy tytuł virgo. Także powiązanie z grupą dziewic kobiet, które - jak władczyni - w istocie nimi nie były, znajduje w kulturze religijnej epoki swoje analogie. Jak zauważyła analizująca wczesnośredniowieczne litanie Felice Lifshitz, choć mężczyźni w nich występujący przynależą do różnych kategorii (apostołowie, męczennicy, wyznawcy itd.), grupa żeńska jest całkowicie homogeniczna. Określana jest ona jako virgines, mimo że obejmuje tak naprawdę wszystkie kobiety, w tym także np. wdowy czy postaci takie jak Maria Magdalena ${ }^{130}$. Choć, jak zauważają w odniesieniu do czystości Donald Weinstein i Rudolph Bell - „żadna inna cnota [--] nie była tak zasadnicza dla zarówno przedstawiania, jak i postrzegania świętego życia"131, trudno nie odnieść wrażenia, że w wypadku kobiet na ową czystość i jej najwyższy szczebel - dziewictwo - kładziono większy nacisk. I to także mogło sprzyjać temu, że to właśnie w kontekście świętych dziewic jako jedna z nich, ich przywódczyni i koronatorka pojawia się Maria Panna.

Właśnie jako źródło świętości i droga do zaślubin z samym Królem królów, stanowi też dziewictwo źródło szczególnej siły, a także władzy i religijnego autorytetu. Korzystali z niego duchowni - opatki, opaci, żyjący w celibacie biskupi i papieże, odwołujący się przy tym do postaci Królowej dziewic, Marii Panny. Korzystała też władczyni, której pozycja była w szczególny sposób powiązana z dziewicami, zwłaszcza świętymi dziewicami, a przez nie i z Marią Panną. Wreszcie zapośredniczony przez wspólnoty dziewic związek z dziewictwem stawać się mógł źródłem szczególnej Bożej protekcji i władzy także dla całych rodów, które - aby je osiągnąć - fundowały klasztory konsekrowanych dziewic i oddawały swe córki na oblubienice Chrystusa, aby dzięki temu otrzymać nagrodę wieczną, ale i ziemskie powodzenie ${ }^{132}$. Tak było i w przypadku

130 F. Lifshitz, op. cit., zwł. s. 87-90.

131 D. Weinstein, R.M. Bell, Saints \& society. The two Worlds of Western Christendom 1000-1700, Chicago-London 1982, s. 73.

132 O popularności klasztorów żeńskich wśród saskich elit por. przede wszystkim K.J. Leyser, op. cit., zwł. s. 63-74; M. Parisse, Les chanoinesses dans l'Empire germanique (IX ${ }^{e}-X I^{e}$ siècles), „Francia” 6, 1978, s. 107-126 (passim); idem, Les femmes au monastère dans le Nord de l'Allemagne du IX ${ }^{e}$ au XI siècle. Conditions sociales et religieuses, w: Frauen in Spätantike und Frühmittelalter. Lebensbedingungen - Lebensnormen - Lebensformen, red. W. Affeldt, Sigmaringen 1990, s. 311-324 (passim); idem, Die Frauenstifte und Frauenklöster 
Liudolfingów ${ }^{133}$, którzy władzę zawdzięczali - wedle słów Hrotswity zasługom dziewic z ufundowanego przez nich Gandersheim, a którzy jednocześnie chętnie odwoływali się do opieki samej Królowej dziewic, Marii Panny. $\mathrm{W}$ istocie, jeśli w myśleniu epoki dziewictwo stanowiło cnotę szczególną, dającą osobie praktykującej ją najbliższą możliwą, bo oblubieńczą więź z Chrystusem, a więc tym, od którego pochodzi wszelka władza, to ów związek między władzą a dziewictwem staje się w pewien sposób oczywisty.

\section{Streszczenie}

Artykuł dotyczy znaczenia, jakie w religijności i ideologii władzy w ottońskiej Rzeszy miało święte dziewictwo. Analizie poddana zostaje szczególna rola, jaką odgrywało ono w budowaniu pozycji i autorytetu ludzi Kościoła obojga płci. To znaczenie dziewictwa znajdowało zwój wyraz w ich szczególnej dewocji maryjnej, podkreślającej zwłaszcza ten właśnie przymiot Bogarodzicy. Tymczasem już w czasach karolińskich uważano, że z jednej strony królewska pozycja Marii Panny jest powiązana z jej dziewictwem, z drugiej - że jest ona pierwszą spośród świętych dziewic, nazywaną czasem wprost ich królową. W efekcie $\mathrm{w}$ okresie ottońskim spotykamy też Bogarodzicę jako koronatorkę świętych dziewic, a więc tę, która udziela im niebiańskiej nagrody. Prowadzi to do pytania o znaczenie, jakie dziewictwo, rozumiane jako źródło władzy, miało dla ottońskich władczyń. Artykuł pokazuje, że dla pozycji zajmowanej przez władczynie było ono kluczowe. To ono właśnie tłumaczy związki między osobą królowej a Marią Panną, które w istocie są raczej pośrednie niż - jak się często sugeruje - bezpośrednie; Bogarodzica jest punktem odniesienia dla małżonki władcy przede wszystkim jako pierwsza ze świętych dziewic. Znaczenie idei dziewictwa dla ideologii władzy związanej z królową każe postawić pytanie o związek między dziewictwem a płcią. Odpowiedzi są tu niejednoznaczne. $Z$ jednej bowiem strony cnota ta jest pokazywana jako istotna tak dla mężczyzn, jak i kobiet, w obu też wypadkach w sposób szczególny patronuje jej Maria Panna. Z drugiej - wstrzemięźliwość seksualna wydaje się być szczególnie uwypuklana właśnie w wypadku kobiet, jako tak istotny komponent rozumienia roli władczyni, jak i choćby kobiecego wzorca świętości.

in Sachsen vom 10. bis zur Mitte des 12. Jahrhunderts, w: Die Salier und das Reich, red. S. Weinfurter, t. 2: Die Reichskirche in der Salierzeit, Sigmaringen 1991, s. 465-502 (passim).

133 O znaczeniu klasztorów żeńskich dla Liudolfingów patrz literatura wskazana w poprzednim przypisie oraz G. Althoff, Gandersheim und Quedlinburg. Ottonische Frauenklöster als Herrschafts- und Überlieferungszentrum, „Frühmittelalterliche Studien” 25, 1991, s. 123-144 (passim), a także G. Pac, Kobiety $w$ dynastii Piastów. Rola społeczna piastowskich żon i córek do połowy XII wieku. Studium porównawcze, Toruń 2013, s. 433-438, gdzie dalsza literatura. 


\section{Holy Virginity, the Queen of Virgins, and Power in the Ottonian Reich}

The article deals with the importance of holy virginity for the devotion and ideology of power in the Ottonian Reich. The analysis focuses on its special role in establishing the authority and position of people of the Church, of both genders. The importance of virginity found its expression in their special Marian devotion, emphasising the virginity of the Virgin. It was as early as Carolingian times that, on the one hand, the regal position of the Virgin Mary was seen as related to her virginity, while, on the other hand, the Virgin Mary was regarded as the first among the holy virgins, and was often called their queen. As a result, often in the Ottonian period we see the Virgin Mary as the one who presented holy virgins with their crown, that is, provided them with the heavenly reward. This leads to the question about the significance of virginity, understood as the source of power, for Ottonian female rulers. The article reveals that it was of key importance for their position. It explained relations between the queen and the Virgin Mary which, in fact, were indirect rather than direct, contrary to what has been often suggested; the Virgin Mary is the point of reference for the king's wife primarily as the first among the holy virgins. This importance of the idea of virginity for the ideology of queenship prompts the question about the relationship between virginity and gender. The answers, however, are not unambiguous. On the one hand, the virtue of chastity was depicted as important for both men and women, and in both of these cases it was under special patronage of the Virgin Mary. On the other hand, special emphasis was placed on female virginity as an important factor both of the queen's role, and of the female model of sanctity.

Translated by Grażyna Waluga

\section{Bibliografia}

Abbo, Liber Apologeticus, PL 139, kol. 461-472.

Äbtissin Hitda und der Hitda-Codex (Universitäts- und Landesbibliothek Darmstadt, Hs. 1640). Forschungen zu einem Hauptwerk der ottonischen Kölner Buchmalerei, red. Klaus G. Beuckers, Wissenschaftliche Buchgesellschaft, Darmstadt 2013.

Adso, De ortu et tempore Antichristi. Necnon et tractatus qui ab eo dependunt, wyd. Daniel Verhelst, CCCM 45, Brepols, Turnhout 1976.

Algermissen Konrad, Persönlichkeit, Leben und Wirken Bernwards, w: Bernward und Godehard von Hildesheim. Ihr Leben und Wirken, red. Konrad Algermissen, Lax, Hildesheim 1960, s. 17-74.

Althoff Gerd, Gandersheim und Quedlinburg. Ottonische Frauenklöster als Herrschaftsund Überlieferungszentrum, „Frühmittelalterliche Studien” 25, 1991, s. 123-144.

Althoff Gerd, Probleme um die dos der Königinnen im 10. und 11. Jahrhundert, w: Veuves et veuvage dans le haut Moyen Âge, red. Michel Parisse, Editions A. et J. Picard, Paris 1993, s. 123-132. 
Bauer Gerd, „Neue” Bernward-Handschriften, w: Bernwardinische Kunst. Bericht über ein wissenschaftliches Symposium in Hildesheim vom 10.10. bis 13.10.1984, red. Martin Gosebruch, Frank N. Steigerwald, Goltze, Göttingen 1988, s. 211-235.

Beissel Stephan, Miniaturen aus Prüm, „Zeitschrift für christliche Kunst” 19, 1906, 1, kol. 11-22.

Beuckers Klaus G., Winterer Christoph, Einleitung, w: Äbtissin Hitda und der Hitda-Codex (Universitäts- und Landesbibliothek Darmstadt, Hs. 1640). Forschungen zu einem Hauptwerk der ottonischen Kölner Buchmalerei, red. Klaus G. Beuckers, Wissenschaftliche Buchgesellschaft, Darmstadt 2013, s. 7-32.

Bognetti Gianpiero, Marcora Carlo, L'abbazia benedettina di Civate. Note di storia e di arte, Casa del Cieco, Civate 1957.

Bornscheuer Lothar, Miseriae regum. Untersuchungen zum Krisen- und Todesgedanken in der herrschaftstheologischen Vorstellung der ottonisch-salischen Zeit, De Gruyter, Berlin 1968 (Arbeiten zur Frühmittelalterforschung, 4).

Brandt Michael, Der Einband, w: Das Kostbare Evangeliar des Heiligen Bernward, red. Michael Brandt, Prestel, München 1993.

Buc Philippe, Italian Hussies and German Matrons. Liutprand of Cremona on Dynastic Legitimacy, „Frühmittelalterliche Studien” 29, 1995, s. 207-225.

Bugge John, Virginitas. An Essay in the History of a Medieval Idea, Martinus Nijhoff, The Hague 1975.

Bührer-Thierry Geneviève, La reine adultère, „Cahiers de civilisation médiévale $\mathrm{X}^{\mathrm{e}}$ XII ${ }^{\mathrm{e}}$ siècles" 35, 1992, 4 s. 299-312.

Cantarella Glauco Maria, Dziewictwo i Cluny, w: idem, Comites aulae coelestis. Studia $z$ historii, kultury $i$ duchowości Cluny w średniowieczu, red. Tomasz M. Gronowski OSB, Krzysztof Skwierczyński, Kraków 2009 (Źródła monastyczne, t. 47), s. 537-558.

Chierici Sandro, Lombardie romane, Zodiaque, La-Pierre-qui-Vire 1978.

Clayton Mary, The Apocryphal Gospels of Mary in Anglo-Saxon England, Cambridge University Press, Cambridge 1998.

Clayton Mary, The Cult of the Virgin Mary in the Anglo-Saxon England, Cambridge University Press, Cambridge 1990.

Cohen Adam S., Derbes Anne, Bernward and Eve at Hildesheim, „Gesta” 40, 2001, 1, s. $19-38$.

Cohen Adam S., The Art of Reform in a Bavarian Nunnery Around 1000, „Speculum” 74, 1999, 4, s. 992-1020.

Cohen Adam S., The Uta Codex. Art, Philosophy, and Reform in Eleventh-Century Germany, The Pennsylvania State University Press, University Park 2000.

Collins Kristen M., „Visualizing Mary. Innovation and Exegesis in Ottonian Manuscript Illumination", University of Texas at Austin (rozprawa doktorska, mps), 2007.

Corbet Patric, Les saints ottoniens. Sainteté dynastique, sainteté royale et sainteté féminine autour de l'an Mil, Thorbecke Verlag, Sigmaringen 1986.

Corbet Patrick, Les impératrices ottoniennes et le modèle marial. Autour de l'ivoire du château Sforza de Milan, w: Marie. Le culte de la Vierge dans la société médiévale, red. Dominique Iogna-Prat, Éric Palazzo, Daniel Russo, Beauchesne, Paris 1996, s. $109-135$. 
Corpus Antiphonalium Officii, wyd. René-Jean Hesbert, t. 1: Manuscripti „Cursus Romanus", Herder, Roma 1963 (Series Maior Fontes, 7).

Dachowski Elizabeth, Tertius est optimus. Marriage, Continence, and Virginity in the Politics of Late Tenth- and Early Eleventh-Century Francia, w: Medieval Purity and Piety. Essays on Medieval Clerical Celibacy and Religious Reform, red. Michael Frassetto, Garland Publishing, New York-London 1998, s. 117-129.

Der Pseudo-Hieronymus-Brief IX „Cogitis Me”, Ein erster Marianischer Traktat des Mittelalters von Paschasius Radbert, red. i wstęp Albert Ripberger, Universitätsverlag, Freiburg 1962 (Spicilegium Friburgense, 9).

Deshman Robert, Christus rex et magi reges. Kingship and Christology in Ottonian and Anglo-Saxon Art, „Frühmittelalterliche Studien” 10, 1976, s. 367-405.

Deshman Robert, The Benedictional of Æthelwold, Princeton University Press, Princeton 1995.

Die älteren Hildesheimer Inschriften bis zum Tod Bischofs Hezilos (†1079), wyd. Wilhelm Berges, Hans-Jürgen Rieckenberg, Vandenhoeck \& Ruprecht, Göttingen 1983.

Die Inschriften der Stadt Hildesheim, t. 2, wyd. Christine Wulf, Hans-Jürgen Rieckenberg, Reichert Verlag, Wiesbaden 2003 (Die Deutschen Inschriften, 58).

Die Ordines für die Weihe und Krönung des Kaisers und der Kaiserin. Ordines coronationis imperialis, wyd. Reinhard Elze, MGH Fontes 9, Hahnsche Buchhandlung, Hannover 1960.

Dodwell Charles R., Turner Derek H., Reichenau Reconsidered. A Re-assessment of the Place of Reichanau in Ottonian Art, Warburg Institute, London 1965.

Elliot Dyan, The Bride of Christ Goes to Hell. Metaphor and Embodiment in the Lives of Pious Women, 200-1500, University of Pennsylvania Press, Philadelphia 2012.

Epistola ad Macedonium, w: Sedulii opera omnia, wyd. Iohannes Huemer, Verlag der Österreichischen Akademie der Wissenschaften, Wien 2007 (Corpus scriptorum ecclesiasticorum Latinorum, 10; wyd. 1 1885).

Erkens Franz-Reiner, „Sicut Esther regina”. Die westfränkische Königin als „consors regni”, „Francia” 20, 1993, 1, s. 15-38.

Fehrenbach Frank, Die Goldene Madonna im Essener Münster. Der Körper der Königin, Edition Tertium, Essen 1996.

Figurski Paweł, Das sakramentale Herrscherbild in der politischen Kultur des Frühmittelalters, „Frühmittelalterliche Studien” 50, 2016, s. 129-161.

Figurski Paweł, Duchowość maryjna biskupa Bernwarda z Hildesheim, „Salvatoris Mater" 13, 2011, 1-2, s. 1-49.

F[illitz] H[ermann], Krone, w: Bernward von Hildesheim und das Zeitalter der Ottonen, red. Michael Brandt, Arne Eggebrechtt, Bernward Verlag - Verlag Philipp von Zabern, Hildesheim-Mainz am Rhein 1993, t. 2, nr II-32, s. 79-81.

Francovich Géza de, Arte carolingia ed ottoniana in Lombardia, „Römisches Jahrbuch für Kunstgeschichte" 6, 1942-1944, s. 113-255.

Fulton Rachel, „Quae est ista quae ascendit sicut aurora consurgens?”. The Song of Songs as the Historia for the Office of the Assumption, „Mediaeval Studies” 60, 1998, s. 55-122.

Gallistl Bernhard, Die Tür des Bischofs Bernward und ihr ikonographisches Programm, w: Le porte di bronzo dall'antichità al secolo XIII, t. 1: Testi, red. Salvatorino Salomi, Instituto dell'Enciclopedia Italiana fonda da G. Treccani, Roma 1990, s. 145-181. 
Gastoué Amédée, La musique d'Église. Études historiques, esthétiques et pratiques, Janin frères, Lyon 1911.

Gijsel Jan, Die unmittelbare Textüberlieferung des sog. Pseudo-Matthäus, Paleis der Academiën, Brussel 1981 (Verhandelingen van de Koninklijke Academie voor Wetenschappen, Letteren en Schone Kunsten van België, Klasse der Letteren, Jaargang 43, nr 96).

Goetting Hans, Das Bistum Hildesheim, t. 3: Die Hildesheimer Bischöfe von 815 bis 1221 (1227), Walter de Gruyter, Berlin-New York 1984 (Germania Sacra N. F. 20).

Goez Werner, Italien zur Zeit Bernwards, w: Bernward von Hildesheim und das Zeitalter der Ottonen, red. Michael Brandt, Arne Eggebrechtt, t. 1, Bernward Verlag Verlag Philipp von Zabern, Hildesheim-Mainz am Rhein 1993, s. 123-132.

Goullet Monique, Hrotsvita de Gandersheim, Maria, w: Marie. Le culte de la Vierge dans la société médiévale, red. Dominique Iogna-Prat, Éric Palazzo, Daniel Russo, Beauchesne, Paris 1996, s. 441-470.

Guldan Ernst, Eva und Maria. Eine Antithese als Bildmotiv, Verlag Hermann Böhlaus Nachf., Graz-Köln 1966.

Gussone Nikolaus, Trauung und Krönung. Zur Hochzeit der byzantinischen Prinzessin Theophanu mit Kaiser Otto II., w: Kaiserin Theophanu. Begegnung des Ostens und Westens um die Wende des ersten Jahrtausends, t. 2, red. Anton von Euw, Peter Schreiner, Schnütgen-Museum der Stadt Köln, Köln 1991, s. 161-173.

Hageman Mariëlle, Between the Imperial and the Sacred. The Gesture of Coronation in Carolingian and Ottonian Images, w: New Approaches to Medieval Communication, red. Marco Mostert, Brepols, Turnhout 1999, s. 127-163.

Hahn Cynthia J., Passio Kiliani. Ps. Theotimus, Passio Margaretae. Orationes. Kommentarbar, Akademische Druck- u. Verlagsanstalt, Graz 1988.

Hehl Ernst-Dieter, Maria und das ottonisch-salische Königtum. Urkunden, Liturgie, Bilder, „Historisches Jahrbuch” 117, 1997, s. 271-310.

Hoffmann Hartmut, Buchkunst und Königtum im ottonischen und frühsalischen Reich. Textband, Anton Hiersemann, Stuttgart 1986 (Schriften der Monumenta Germaniae Historica, t. 30, I).

Holder Alfred, Die Reichenauer Handschriften, t. 1, Die Pergamenthandschriften B.G. Teubner, Leipzig 1906 (Die Handschriften der Badischen Landesbibliothek in Karlsruhe, 5; reprint Wiesbaden 1970).

Hrotsvit, Primordia coenobii Gandeshamensis, w: Hrotsvit, Opera Omnia, wyd. Walter Berschin, Monachii et Lipsiae 2001 (Bibliotheca Scriptorum Graecorum et Romanorum Teubneriana), s. 306-329.

Hrotsvit, Prologus [I] ad Gerbergam abbatissam, w: Hrotsvit, Opera Omnia, wyd. Walter Berschin (Bibliotheca Scriptorum Graecorum et Romanorum Teubneriana), Saur, Monachii et Lipsiae 2001, s. 3.

In Assumptione Sanctae Mariae, wyd. W. von den Steinen, w: Notkeri Liber Ymnorum editio princeps authentica latine et theotisce (= Wolfgang von den Steinen, Notker der Dichter und seine geistige Welt, Editionsband), A. Francke, Bern 1948, s. 66.

Iogna-Prat Dominique, Continence et virginité dans conception clunisienne de l'ordre du monde autour de l'an mil, „Comptes rendus des séances de l'Académie des Inscriptions et Belles-Lettres" 129, 1985, 1, s. 127-146. 
Iogna-Prat Dominique, Entre anges et hommes. Les moines „doctrinaires” de l'an Mil, w: La France de l'an Mil, red. Robert Delort, Seuil, Paris 1990, s. 245-263.

Iogna-Prat Dominique, La Vierge et les „ordines” de couronnement des reines au IX siècle, w: Marie. Le culte de la Vierge dans la société médiévale, red. Dominique Iogna-Prat, Éric Palazzo, Daniel Russo, Beauchesne, Paris 1996, s. 100-107.

Iogna-Prat Dominique, Le culte de la Vierge sous le règne de Charles le Chauve, "Les Cahiers de Saint-Michel de Cuxa" 23, 1992, s. 97-116.

Iogna-Prat Dominique, Politische Aspekte der Marienverehrung in Cluny um das Jahr 1000, w: Maria in der Welt. Marienverehrung im Kontext der Sozialgeschichte 10.18. Jahrhundert, wyd. Claudia Opitz, Hedwig Röckelein, Gabriela Signori, Guy P. Marchal, Chronos Verlag, Zürich 1993, s. 243-251.

$\mathrm{Ka}$ [hsnitz] R[ainer], Bronzetüren im Dom, w: Bernward von Hildesheim und das Zeitalter der Ottonen, red. Michael Brandt, Arne Eggebrechtt, Bernward Verlag - Verlag Philipp von Zabern, Hildesheim-Mainz am Rhein 1993, t. 2, nr VII-33, s. 503-512. Kahsnitz Rainer, Coronas aureas in capite. Zum Allerheiligenbild des Reichenauer Kollekrats in Hildesheim, w: Per assiduum studium Scientiae Adipisci Margaritam. Festgabe für Ursula Nilgen zum 65. Geburtstag, red. Axel Amberger, EOS, St. Ottilien 1997, s. 61-97.

Kahsnitz Rainer, Inhalt und Aufbau der Handschrift, w: Das Kostbare Evangeliar des Heiligen Bernward, red. Michael Brandt, Prestel, München 1993, s. 18-55.

Kahsnitz Rainer, The Gospel Book of Abbess Svanhild of Essen in the John Rylands Library, Cz. 1, „Bulletin of the John Rylands Library” 53, 1970-1971, 1, s. 122-166; cz. 2, „Bulletin of the John Rylands Library” 53, 1970-1971, 2, s. 360-396.

Kantorowicz Ernst H., Laudes regiae. A Study in Liturgical Acclamations and Mediaeval Ruler Worship, University of California Press, Berkeley-Los Angeles 1958.

Kantorowicz Ernst, Ivories and Litanies, „Journal of the Warburg and Courtauld Institutes" 5, 1942, s. 56-81.

Kingsley Jennifer P., The Bernward Gospel. Art, Memory, and the Episcopate in Medieval Germany, The Pennsylvania State University Press, University Park 2014.

Körntgen Ludger, Königsherrschaft und Gottes Gnade. Zu Kontext und Funktion sakraler Vorstellungen in Historiographie und Bildzeugnissen der ottonisch-frühsalischen Zeit, Akademie Verlag, Berlin 2001 (Orbis mediaevalis. Vorstellungenswelten des Mittelalters, 2).

Krüger Astrid, Litanei-Handschriften der Karolingerzeit, MGH, Hilfsmittel, t. 24, Hahnsche Buchhandlung, Hannover 2007.

Küppers Leonhard, Die Goldene Madonna in Essen, w: Die Gottesmutter. Marienbild in Rheinland und in Westfalen, red. Leonhard Küppers, Bongers, Recklinghausen 1974, s. 43-50.

Küppers Leonhard, Paul Mikat, Der Essener Münsterschatz, Fredebeul \& Koenen, Essen 1966.

Lafontaine-Dosogne Jacqueline, Iconographie de l'enfance de la Vierge dans l'Empire byzantin et en Occident, Palais des Académies, Bruxelles 1965 (Académie Royal de Belgique, Classe des Beaux-Arts, Mémoires, Collection in-4o - 2e série, t. 11, fasc. 3bis) (przedruk: 1992).

Lauer Philippe, Les enluminures romanes des manuscrits de la Bibliothèque nationale, Ed. de la Gazette des Beaux-arts, Paris 1927. 
Lawrence Marion, Maria Regina, „The Art Bulletin” 7, 1925, 4, s. 150-161.

Le pontifical romano-germanique du dixième siècle, t. 1, wyd. Cyrille Vogel, Reinhard Elze, Biblioteca apostolica vaticana, Città del Vaticano 1963.

Legimus in ecclesiasticis historiis, wyd. James E. Cross, w: James E. Cross, „Legimus in ecclesiasticis historiis". A Sermon for All Saints, and its use in Old English Prose, „Traditio” 33, 1977, s. 105-121 (wydanie źródłowe), s. 101-135 (całość artykułu).

Leyser Karl J., Rule and Conflict in an Early Medieval Society. Ottonian Saxony, Edward Arnold, London 1979.

Libri de Nativitate Mariae. Pseudo-Matthaei Evangelium. Textus et commentarius, wyd. Jan Gijsel, Corpus Christianorum, Seria Apocryphorum, t. 9, Brepols, Turnhout 1997.

Lidova Maria, The Earliest Images of Maria Regina in Rome and the Byzantine Imperial Iconography, „Niš \& Byzantium” 8, 2010, red. Miša Rakocija, s. 231-243.

Lifshitz Felice, Priestly Women, Virginal Men. Litanies and Their Discontents, w: Gender and Christianity in Medieval Europe. New Perspectives, red. Lisa M. Bittel, F. Lifshnitz, University of Pennsylvania Press, Philadelphia 2008, s. 87-102.

Little Charles T., Avori milanesi del X secolo, w: Il millennio ambrosiano. La città del vescovo dai Carolingi al Barbarossa, red. Carlo Bertelli, Electa, Milano 1988, s. 82-101.

Machilek Franz, Machilek Margarita, Zur Feier des Festes der Praesentatio Mariae und zur Ikonographie des Tempelgangs Marias, „Beiträge zur fränkischen Kunstgeschichte” 1-2, 1995-1996, s. 95-115.

MacLean Simon, Ottonian Queenship, Oxford University Press, Oxford 2017.

MacLean Simon, Queenship, Nunneries and Royal Widowhood in Carolingian Europe, „Past \& Present” 178, 2003, s. 3-38.

MacLean Simon, Reform, Queenship and the End of the World in Tenth-Century France. Adso's „Letter on the Origin and Time of the Antichrist” Reconsidered, „Revue belge de philologie et d'histoire" 86, 2008, s. 645-675.

Macy Gary, Hrotsvit's Theology of Virginitity and Continence, w: A Companion to Hrotsvit of Gandersheim (fl. 960). Contextual and Interpretive Approaches, red. Phyllis R. Brown, Stephen L. Wailes, Brill, Leiden-Boston 2013 (Brill's Companions to the Christan Tradition, 34), s. 63-82.

Mariaux Pierre A., Warmond d'Ivrée et ses images. Politique et creation iconographique autour de l'an mil, Peter Lang, Bern-Berlin-Bruxelles 1997.

Matter E. Ann, The Voice of My Beloved. The Song of Songs in Western Medieval Christianity, University of Pennsylvania Press, Philadelphia 1990.

Mayr-Harting Henry, Ottonian Book Illumination, t. 1, H. Miller Publishers, London 1991.

Mayr-Harting Henry, The Idea of the Assumption of Mary in the West, 800-1200, w: The Church and Mary, red. Robert N. Swanson, The Boydell Press, Woodbridge 2004 (Studies in Church History, 39), s. 86-111.

Michałowski Roman, Princeps fundator. Studium z dziejów kultury politycznej w Polsce X-XIII wieku, Zamek Królewski w Warszawie, Warszawa 1993.

Michałowski Roman, Święty Wojciech - biskup reformator w Europie X wieku, w: Granica wschodnia cywilizacji zachodniej w średniowieczu, red. Zbigniew Dalewski, IH PAN, Warszawa 2014, s. 169-210. 
Nelson Janet L., Early Medieval Rites of Queen-Making and the Shaping of Medieval Queenship, w: Queens and Queenship in Medieval Europe, red. Anne J. Duggan, Boydell and Brewer, Woodbridge 1997, s. 301-315.

Nilgen Ursula, Maria Regina - ein politischer Kultbildtypus, „Römisches Jahrbuch für Kunstgeschichte" 19, 1981, s. 3-33.

Noble Thomas F.X., Images, Iconoclasm and the Carolingians, University of Pennsylvania Press, Philadelphia 2009.

Noble Thomas F.X., Topography, Celebration, and Power. The Making of Papal Rome in the Eighth and Ninth Centuries, w: Topographies of Power in the Early Middle Ages, red. Frans Theuws, Mayke de Jong, E.J. Brill, Leiden 2001, s. 45-91.

Nordenfalk Carl, Milano e l'arte ottoniana. Problemi di fondo signora poco osservati, w: Il millennio ambrosiano. La città del vescovo dai carolingi al Barbarossa, red. Carlo Bertelli, Electa, Milano 1988, s. 102-125.

Odilonis Cluniacensis abbatis sermo XII. De assumption Dei genitricis Mariae, PL 142, kol. 1025-1029.

Opfermann Bernhard, Die liturgischen Herrscherakklamationen im Sacrum Imperium des Mittelalters, Hermann Böhlaus Nachfolger, Weimar 1953.

Osborne John, The Cult of Maria Regina in Early Medieval Rome, „Acta ad archaeologiam et atrium historiam pertinentia" 21, 2008, s. 95-106.

Ott Joachim, Krone und Krönung. Die Verheißung und Verleihung von Kronen in der Kunst von der Spätantike bis um 1200 und die geistige Auslegung der Krone, Verlag Philipp von Zabern, Mainz am Rhein 1998.

Pac Grzegorz, Genitrix Iudith nomine. Judyta Czeska i jej miejsce w Kronice Galla Anonima na tle porównawczym, w: Christianitas Romana. Studia ofiarowane Profesorowi Romanowi Michałowskiemu, red. Krzysztof Skwierczyński, Wydawnictwa Uniwersytetu Warszawskiego, Warszawa 2009, s. 129-157.

Pac Grzegorz, Kobiety w dynastii Piastów. Rola społeczna piastowskich żon i córek do połowy XII wieku. Studium porównawcze, Wydawnictwo Naukowe UMK, Toruń 2013.

Pac Grzegorz, Koronacje władczyń we wcześniejszym średniowieczu - zarys problematyki, w: Gnieźnieńskie koronacje królewskie i ich środkowoeuropejskie konteksty, red. Józef Dobosz, Marzena Matla, Leszek Wetesko, Urząd Miejski w Gnieźnie, Gniezno 2011 (Colloquia Meiaevalia Gnesnensia, 2), s. 43-57.

Pac Grzegorz, Królowa-Matka czy Królowa-Oblubienica? Przemiany w rozumieniu królewskiego statusu Marii Panny i jej relacji z Chrystusem w teologii karolińskiej, w: Płeć i władza w kontekstach historycznych i współczesnych, red. Monika Anna Kubiaczyk, Filip Kubiaczyk, Instytut Kultury Europejskiej UAM, Gniezno 2014 (Gnieźnieńskie Prace Humanistyczne, 1), s. 115-129.

Pac Grzegorz, Obraz małżenstwa w wybranych niemieckich źródłach hagiograficznych X i XI wieku, w: Kult świętych i ideał świętości w średniowieczu, red. Roman Michałowski, Warszawa 2011 (Fasciculi Historici Novi, 11), s. 7-148.

Parisse Michel, Die Frauenstifte und Frauenklöster in Sachsen vom 10. bis zur Mitte des 12. Jahrhunderts, w: Die Salier und das Reich, red. Stefan Weinfurter, t. 2: Die Reichskirche in der Salierzeit, Thorbecke Verlag, Sigmaringen 1991, s. 465-502.

Parisse Michel, Les chanoinesses dans l'Empire germanique (IXe-XIe siècles), „Francia” 6, 1978, s. 107-126. 
Parisse Michel, Les femmes au monastère dans le Nord de l'Allemagne du IXe au XI siècle. Conditions sociales et religieuses, w: Frauen in Spätantike und Frühmittelalter. Lebensbedingungen - Lebensnormen - Lebensformen, red. Werner Affeldt, Thorbecke Verlag, Sigmaringen 1990, s. 311-324.

Parkes Henry, The Making of Liturgy in the Ottonian Church. Books, Music and Ritual in Mainz, 950-1050, Cambridge University Press, Cambridge 2015.

Paulus Winfridus Diaconus, Homilia prima in Assumptione beatae Mariae Virginis, PL 95, kol. 1565-1569.

Peroni Adriano, La plastica in stucco nel. S. Ambrogio di Milano. Arte ottoniana e romanica in Lombardia, w: Kolloquium über spätantike und frühmittelalterliche Skulptur, t. 3, red. Vladimir Milojčić, Verlag Philipp von Zabern, Mainz 1974, s. 59-119.

Prochno Joachim, Schreiber- und Dedikationsbild in der deutschen Buchmalerei, t. 1: Bis zum Ende des 11. Jahrhunderts (800-1100), B.G. Teubner, Leipzig-Berlin 1929.

Rademacher Franz, Die Regina angelorum in der Kunst der frühen Mittelalters, Rheinland Verlag, Düsseldorf 1972 (Die Kunstdenkmäler des Rheinlandes, 17).

Rensing Theodor, Zwei ottonische Kunstwerke des Essener Münsterschatzes, „Westfalen. Hefte für Geschichte, Kunst und Volkskunde" 40, 1962, 1-2, s. 44-52.

Rheinisches Urkundenbuch. Ältere Urkunden bis 1000, t. 2, wyd. Erich Wisplinghoff, red. Wolf-Rüdiger Schleidgen i in., Droste Verlag, Düsseldorf 1994.

Riemer Dieter, Neue Überlegungen zu Hitda, w: Äbtissin Hitda und der Hitda-Codex (Universitäts- und Landesbibliothek Darmstadt, Hs. 1640). Forschungen zu einem Hauptwerk der ottonischen Kölner Buchmalerei, red. Klaus G. Beuckers, Wissenschaftliche Buchgesellschaft, Darmstadt 2013, s. 33-55.

Russo Daniel, Les représentations mariales dans l'art d'Occident. Essai sur la formation d'une tradition iconographique, w: Marie. Le culte de la Vierge dans la société médiévale, red. Dominique Iogna-Prat, Éric Palazzo, Daniel Russo, Beauchesne, Paris 1996, s. 194-209.

Scheffczyk Leo, Das Mariengeheimnis in Frömmigkeit und Lehre der Karolingerzeit, St. Benno-Verlag, Leipzig 1959 (Erfurter Theologische Studien, 5).

Schnitzler Hermann, Ein frühottonisches Fuldaer Kunstwerk des Essener Münsterschatzes, w: Studien zur Buchmalerei und Goldschmiedekunst des Mittelalters. Festschrift für Karl Hermann Usener zum 60. Geburtstag am 19. August 1965, red. Frieda Dettweiler, Herbert Köllner, Peter A. Riedl, Verlag des Kunstgeschichtlichen Seminars der Universität, Marburg 1967, s. 115-118.

Schnitzler Hermann, Rheinische Schatzkammer. Tafelband, L. Schwann, Düsseldorf 1957.

Schoppmeyer Heinrich, Essen, w: Lexikon des Mittelalters, t. 4, Artemis Verlag, München-Zürich 1989, kol. 22-23.

Schramm Percy E., Die deutschen Kaiser und Könige in Bildern ihrer Zeit 751-1190, Prestel Verlag, München 1983.

Schramm Percy E., Herrschaftszeichen und Staatssymbolik. Beiträge zu ihrer Geschichte vom dritten bis zum sechzehnten Jahrhundert, t. 2, Hiersemann, Stuttgart 1955 (Schriften der MGH, 13/II).

Schramm Percy E., Mütherich Florentine, Ein Beitrag zur Herrschergeschichte von Karl dem Großen bis Friedrich II. 768-1250, Prestel Verlag, München 1962. 
Schulze-Dörrlamm Mechthild, Die Kaiserkrone Konrads II. (1024-1039). Eine archäologische Untersuchung zu Alter und Herkunft der Reichskrone, Thorbecke Verlag, Sigmaringen 1991.

Smith Julia M.H., Gender and Ideology in the Early Middle Ages, w: Gender and Christian Religion, red. Robert N. Swanson, The Boydell Press, Woodbridge 1998 (Studies in Church History, 34), s. 51-73.

Sprengler-Ruppenthal Anneliese, Zur Theologie des consors-regni Formel in der sächsischen Königs- und Kaiserzeit, ,Jahrbuch des Gesellschaft für niedersächsische Kirchengeschichte" 83, 1985 (= Festschrift zum 65. Geburtstag von Landessuperintendent i. R. Dr. Kurt Schmidt-Clausen, Abt von Amelungsborn, red. Hans-Walter Krumweide), s. 93-100.

Stinehart Anne Catherine, „Renowned Queen Mother Mathilda”. Ideals and Realities of Ottonian Queenship in the Vitae Mathildis reginae (Mathilda of Saxony, 895?-968), „Essays in History” 40, 1998, http://www.essaysinhistory.com/renownedqueen-mother-mathilda-ideals-and-realities-of-ottonian-queenship-in-thevitae-mathildis-reginae-mathilda-of-saxony-895-968/ (dostęp: 17 IX 2018).

Stroll Mary, Maria Regina. Papal Symbol, w: Queens and Queenship in Medieval Europe, red. Anne J. Duggan, Boydell and Brewer, Woodbridge 1997, s. 173-203.

Szczepański Michał T., Proroctwo i obietnica. Nadprzyrodzone przesłanki władzy Ottonów w ujęciu Hrotsvit z Gandersheim, w: Christianitas Romana. Studia ofiarowane Romanowi Michałowskiemu, red. Krzysztof Skwierczyński, Wydawnictwa Uniwersytetu Warszawskiego, Warszawa 2009, s. 104-119.

Thérel Marie-Louise, A l'origine du décor du portail occidental de Notre-Dame de Senlis. Le triomphe de la Vierge-Église. Sources historiques, littéraires et iconographiques, Éditions du Centre national de la Recherche scientifique, Paris 1984.

Thietmari Merseburgensis episcopi Chronicon, wyd. Robert Holtzmann, MGH SrG., Nova series, t. 9, Berolini 1935.

Tronzo William, The Hildesheim Doors. An Iconographic Source and Its Implications, „Zeitschrift für Kunstgeschichte” 46, 1983, 4, s. 357-366.

Urkundenbuch des Hochstifts Hildesheim und seiner Bischöfe, t. 1, wyd. Karl Janicke, S. Hirzel, Leipzig 1896 (Publikationen aus den königlich-preußischen Staatsarchiven, 65).

Venanti honori clementiani Fortunati presbyteri italici opera poetica, wyd. Friedrich Leo, MGH Auct. Ant., t. 4, cz. 1, Apud Weidmannos, Berolini 1881.

Verdier Philippe, Le couronnement de la Vierge. Les origines et les premiers développements d'un thème iconographique, Institut d'études medievales - Vrin, Montréal-Paris 1980.

Vita Bernwardi episcopi Hildesheimensis auctore Thangmaro, wyd. Georg H. Pertz, MGH SS 4, Impensis Bibliopolii Hahniani, Hannoverae 1841, s. 754-782.

Vita Mathildis reginae posterior, wyd. Bernd Schütte, MGH SrG in usum scholarum, t. 66, Hannover 1994, s. 143-202.

Wailes Stephen L., Beyond Virginity. Flesh and Spirit in the Plays of Hrotsvit of Gandersheim, „Speculum” 76, 2001, 1, s. 1-27.

Weinstein Donald, Rudolph M. Bell, Saints \& society. The two Worlds of Western Christendom 1000-1700, University of Chicago Press, Chicago-London 1982. 
Weitzmann-Fiedler Josepha, Zur Illustration der Margaretenlegende, „Münchner Jahrbuch der bildenden Kunst" 17, 1966, s. 17-48.

Wessenberg Rudolf, Bernwardinische Plastik. Zur ottonischen Kunst unter Bischof Bernward von Hildesheim, Deutscher Verein für Kunstwissenschaft, Berlin 1955.

Weston Lisa M.C., Virginity and Other Sexualities, w: A Companion to Hrotsvit of Gandersheim (fl. 960). Contextual and Interpretive Approaches, red. Phyllis R. Brown, Stephen L. Wailes Brill, Leiden-Boston 2013 (Brill's Companions to the Christan Tradition, 34), s. 267-285.

Zimmermann Walther, Das Münster zu Essen, Fredebeul \& Koenen Verlag, Essen 1956 (Kunstdenkmäler des Rheinlands, t. 3).

Biogram: Grzegorz Pac - nr ORCID 0000-0001-8371-9560, doktor historii, zatrudniony w Instytucie Historycznym Uniwersytetu Warszawskiego. Obszar zainteresowań: wczesne i pełne średniowiecze w Polsce i Europie, społeczna rola kobiet, w tym władczyń, ideologia władzy, hagiografia i kult świętych, w tym NMP, monastycyzm; członek redakcji kwartalnika „Więź” i „Przeglądu Humanistycznego”; kontakt: gl.pac@uw.edu.pl. 


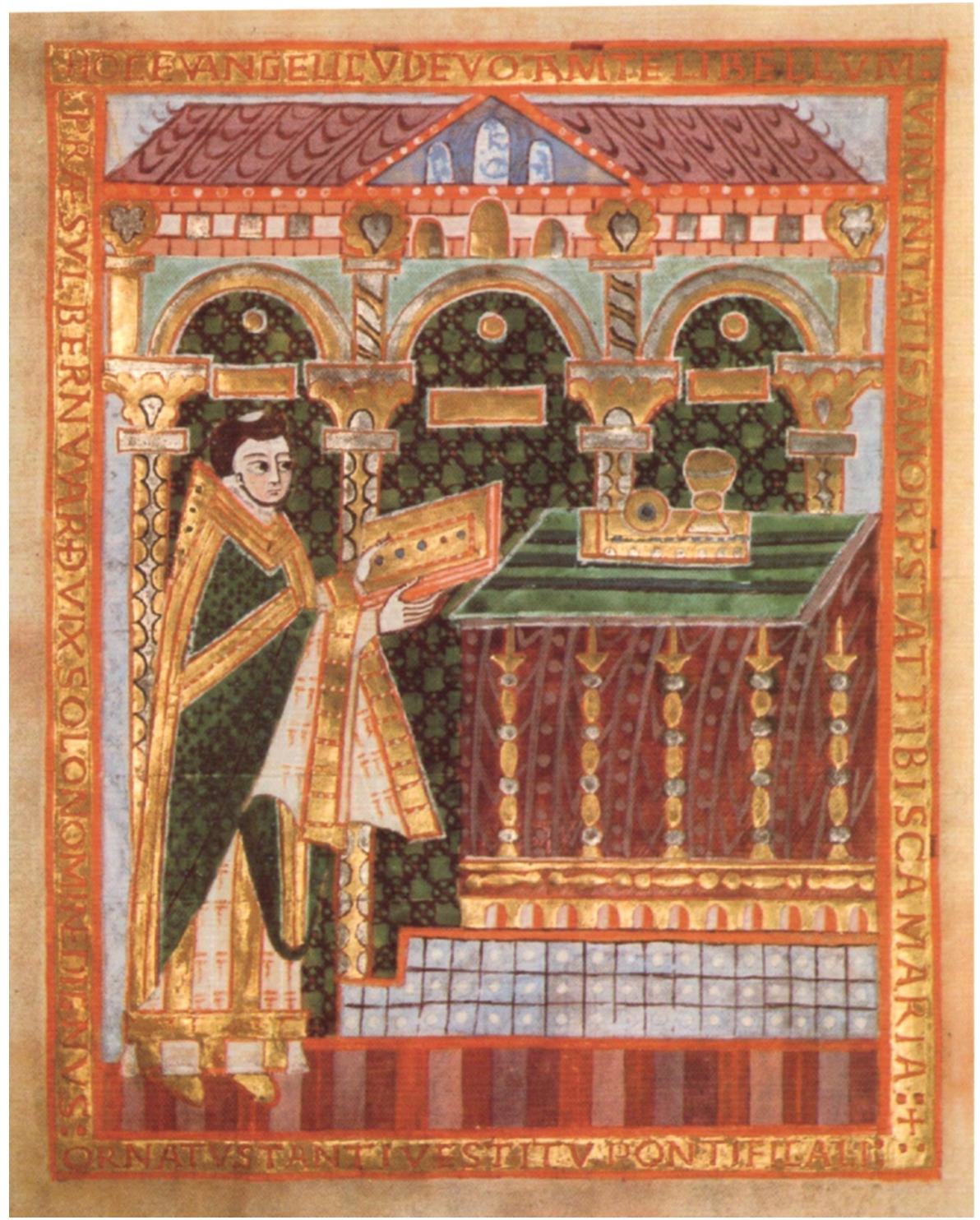

1. Scena dedykacyjna, Kosztowny Ewangeliarz, Hildesheim, Domschatz und Dom-Museum, Ms. 18, fol. 16v-17r. Źródło: domena publiczna, Wikipedia Commons. 


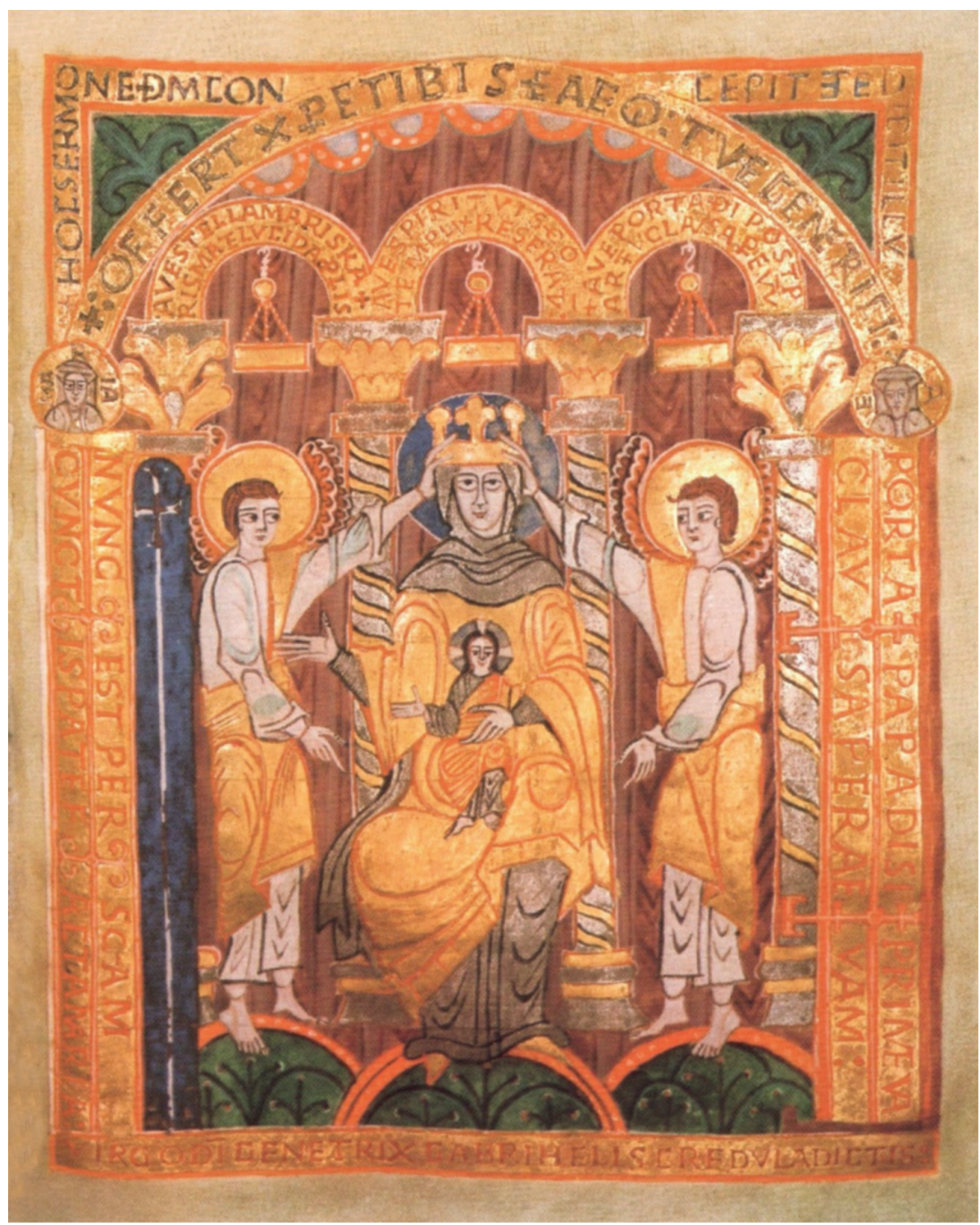




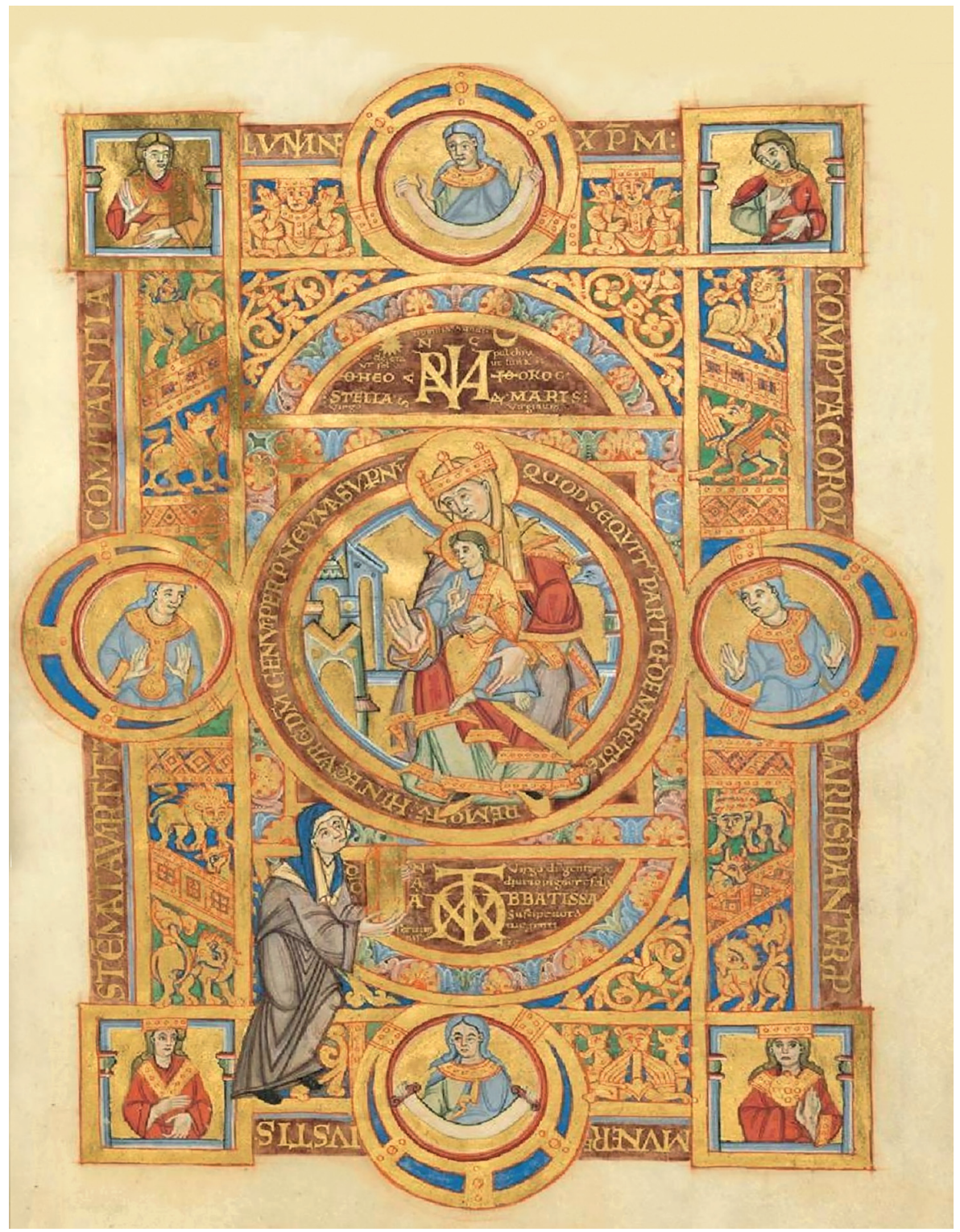

2. Scena dedykacyjna, Ewangeliarz Uty, Monachium, Bayerische Staatsbibliothek, Clm 13601, fol. 2r. Źródło: Bayerische Staatsbibliothek - Münchener Digitalisierungszentrum. Digitale Bibliothek, licencja Creative Commons CC-BY-NC-SA 4.0. 


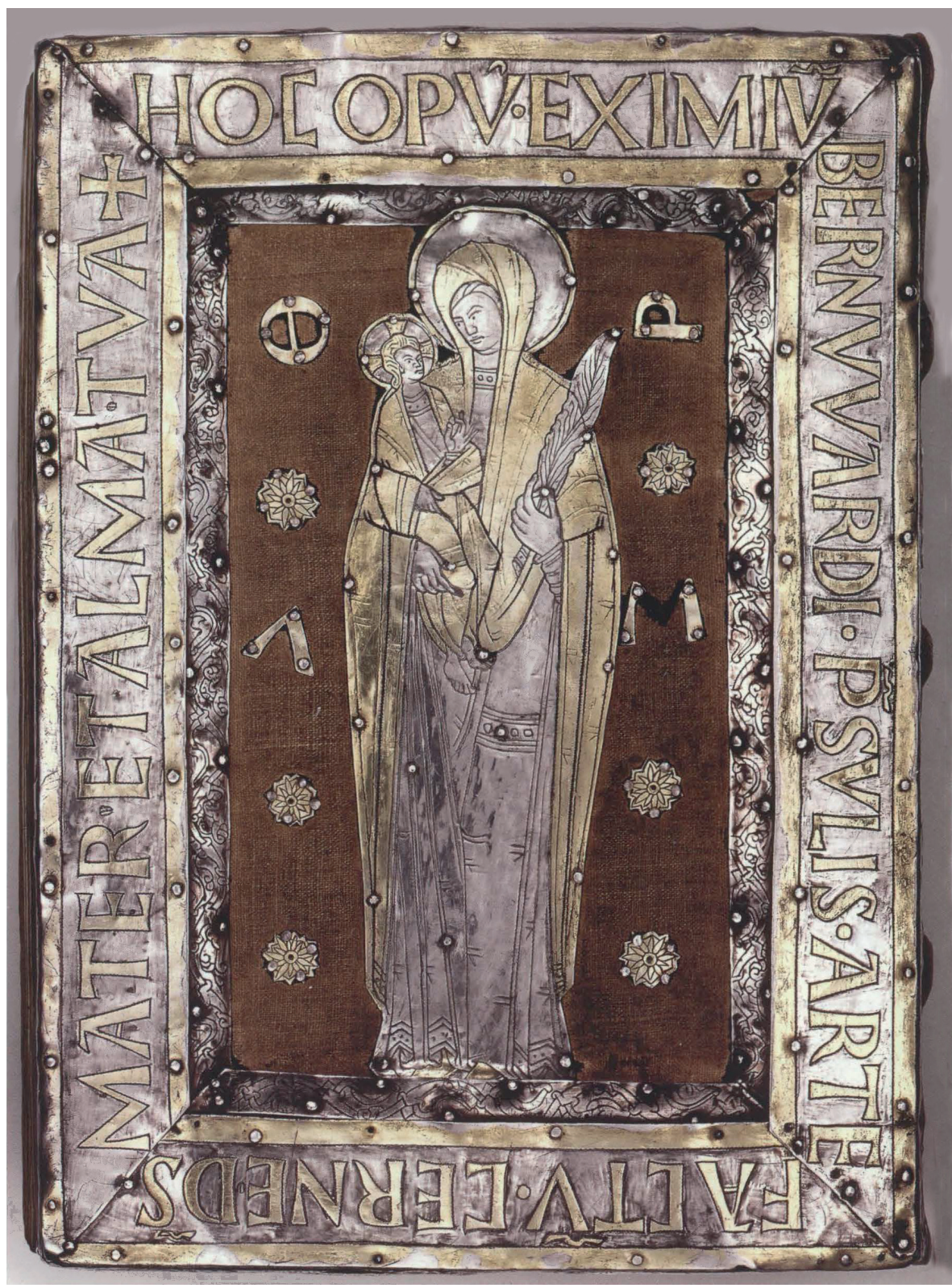

3. Tylna oprawa, Kosztowny Ewangeliarz, Hildesheim, Domschatz und Dom-Museum, Ms. 18. Źródło: J.P. Kingsley, The Bernward Gospel. Art, Memory, and the Episcopate in Medieval Germany, University Park 2014, il. 18. 


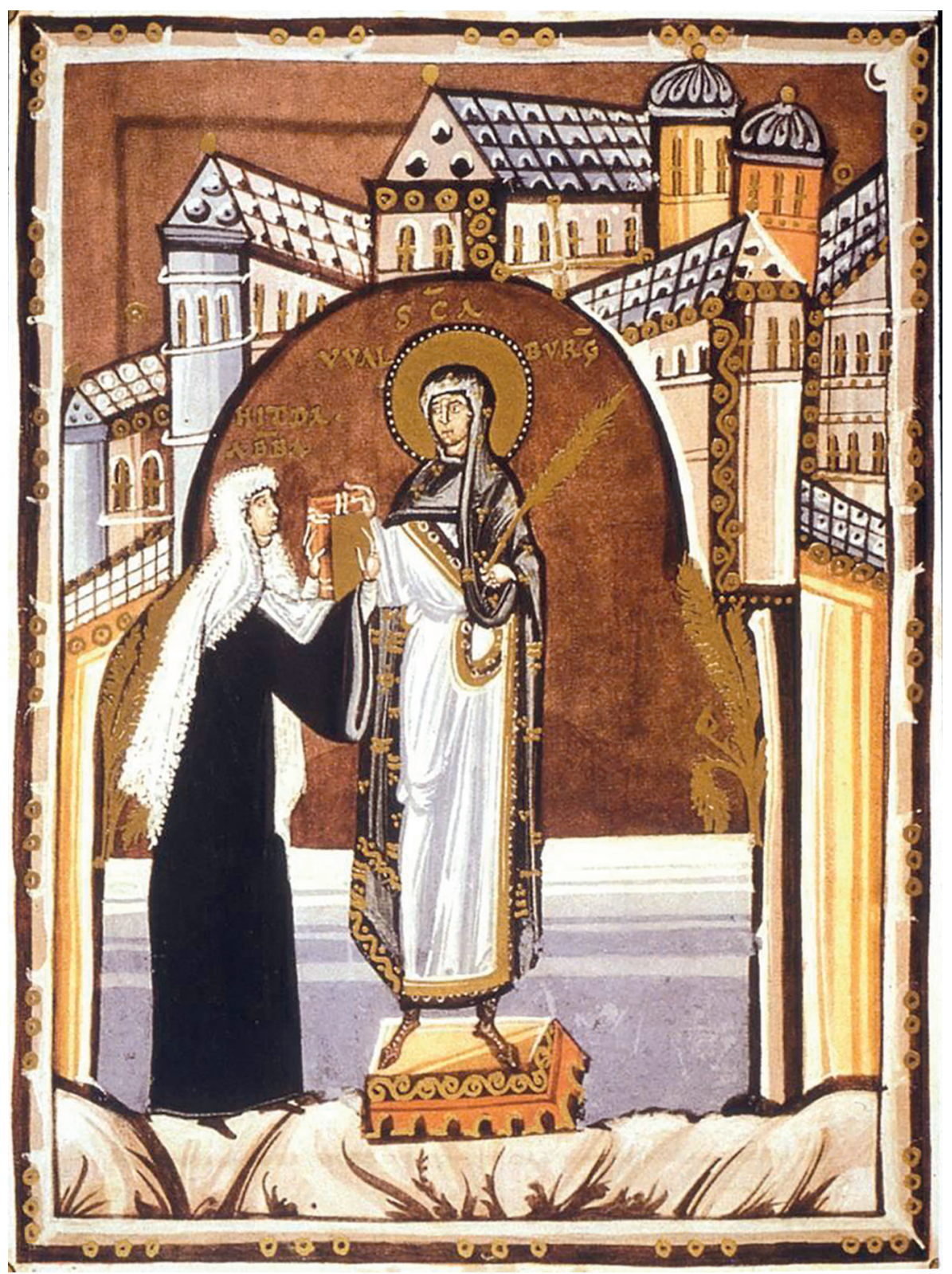

4. Scena dedykacyjna, Kodeks Hitdy, Darmstadt, Universitäts- und Landesbibliothek, Cod. 1640, fol. 6r. Źródło: domena publiczna, Wikipedia Commons. 


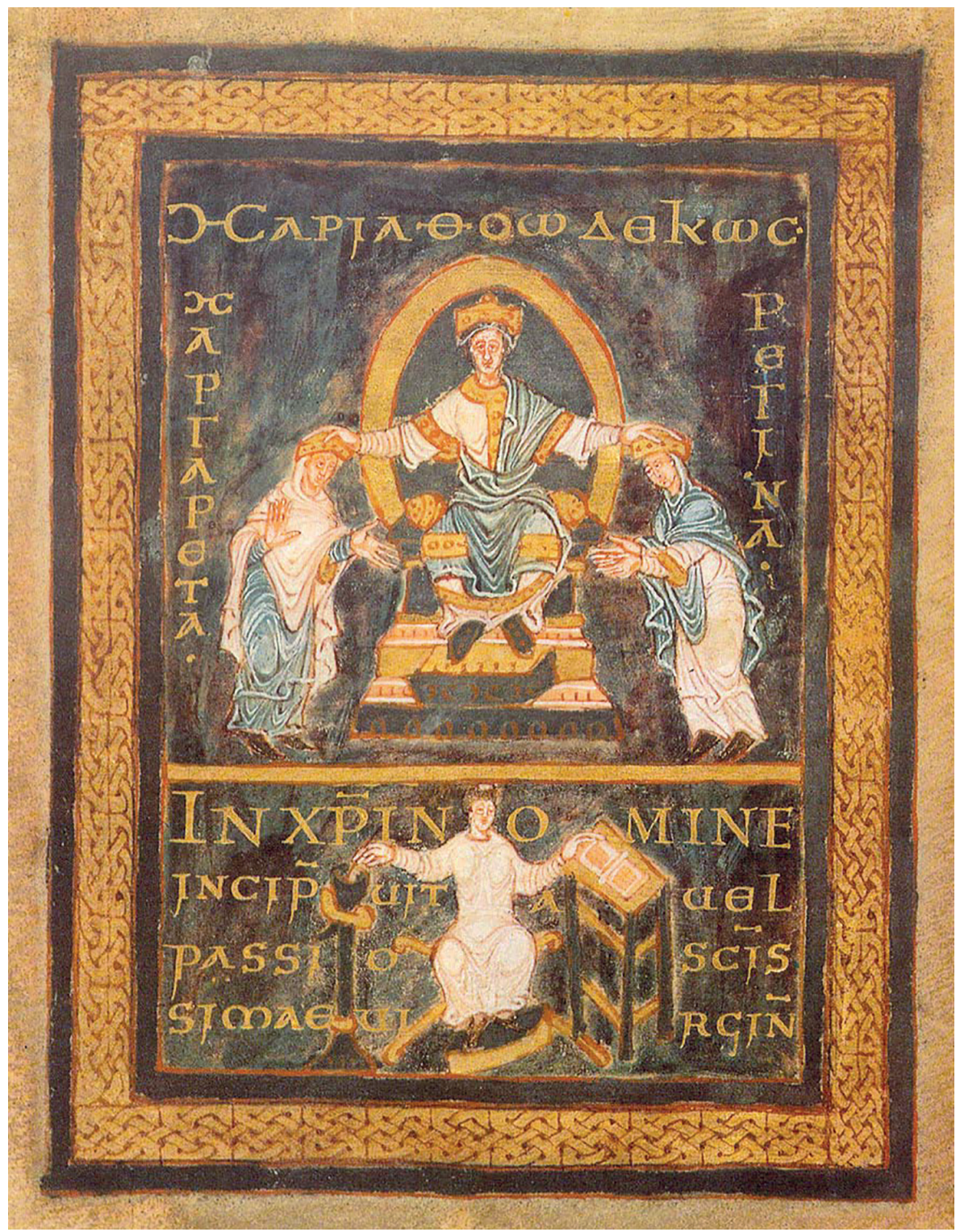

5. Scena rozpoczynająca Żywot św. Małgorzaty, Kodeks z żywotem św. Kiliana i św. Małgorzaty, Hannover, Niedersächsische Landesbibliothek Ms. I 189, fol. 11v. Źródło: K.M. Collins, „Visualizing Mary. Innovation and Exegesis in Ottonian Manuscript Illumination", University of Texas at Austin (rozprawa doktorska, mps), 2007, il. 44 , s. 209. 